\title{
HIV-Related Disability in HIV Hyper-Endemic Countries: A Scoping Review*
}

\author{
Jill Hanass-Hancock ${ }^{1}$, Ilaria Regondi ${ }^{1}$, Leonie van Egeraat $^{1,2}$, Stephanie Nixon ${ }^{1,3}$ \\ ${ }^{1}$ Health Economics and HIV/AIDS Research Division, University of KwaZulu-Natal, Westville Campus, Durban, South Africa; \\ ${ }^{2}$ University of Amsterdam, Amsterdam, The Netherlands; ${ }^{3}$ International Centre for Disability and Rehabilitation, Department of Phy- \\ sical Therapy, University of Toronto, Toronto, Canada. \\ Email: hanasshj@ukzn.ac.za
}

Received May $7^{\text {th }}, 2013$; revised June $7^{\text {th }}, 2013$; accepted July $7^{\text {th }}, 2013$

Copyright (C) 2013 Jill Hanass-Hancock et al. This is an open access article distributed under the Creative Commons Attribution License, which permits unrestricted use, distribution, and reproduction in any medium, provided the original work is properly cited.

\begin{abstract}
Background: In the era of enhanced access to ART, many people live longer lives but with episodes of disability resulting from HIV, HIV-related conditions, and/or as side-effects of ART. It is crucial to understand the extent of disability among people living with HIV in high-prevalence settings to inform choices regarding care, policy and research. This article presents the results of the first scoping review to examine the extent, nature and range of disability among people living with HIV in HIV hyper-endemic countries. Methods: This scoping review used the World Health Organization's International Classification of Functioning, Disability and Health (ICF) to conceptualize "disability". A systematic search of electronic databases was conducted using specific keyword and subject heading combinations. Identified publications were screened and reviewed according to inclusion/exclusion criteria. Data were systematically extracted and reviewed for quality. Extracted data were reviewed for patterns related to methods or results. Results were aligned with the corresponding ICF code. Results: Forty-one articles were included, reporting data from 38 unique studies. Most (78\%) of the studies were conducted in South Africa; five in Botswana, one in Zimbabwe and Lesotho, and none in Swaziland. Almost all studies recruited more females than males. All studies except two were in adults. The studies indicate that people living with HIV experience a variety of disabilities. Impairments in body structure/function comprise the majority of data, with particular focus on mental function. Data on activity limitations and participations restriction were limited, however, they were recorded. They indicate severe impact on people's life and possible adherence. Conclusions: We argue that the time has come to elevate the focus holistically on health and life-related consequences of living with HIV and to integrate disability into the discussions and approaches to HIV care.
\end{abstract}

Keywords: Public Health; Disability; HIV/AIDS; Africa; Morbidity

\section{Background}

The experience of HIV is shifting in hyper-endemic countries now that access to free antiretroviral therapy (ART) is becoming more widespread [1,2]. Many people living with HIV who can access and tolerate ART are living longer lives [3]. However, increased longevity can be accompanied by a diverse range of health-related challenges [3], which may be termed disability [4-7]. This changing experience calls for a shift in how we con-

\footnotetext{
*Comprting interests: The authors have no competing interests to declare.

Authors' contributions: JHH led the project, wrote the first and subsequent drafts of the manuscript, and read and approved the final manuscript; IR, LvE, and SN helped conduct the review, contributed to writing of the manuscript, and read and approved the final manuscript.
}

ceptualize HIV in order to inform responses within this new era $[4,8]$.

Disability and rehabilitation frameworks became useful for HIV policy-makers, advocates and researchers upon the advent of ART in resource-rich countries in the mid1990s [9]. In particular, the World Health Organization's International Classification of Functioning, Disability and Health [10] is a framework that has proven helpful in understanding and taking action on HIV [8-14]. The ICF has also been used for better understanding the disability dimensions of other health conditions in Southern Africa [7,15-17]. As such, the ICF offers a potentially useful framework for considering the experience of HIV in the era of enhanced access to ART in Southern Africa.

In the ICF framework, disability is understood as a 
"complex phenomenon that manifests itself at the body, person and social level" [18]. The ICF is concerned with function at three levels, which are termed structure/function (or impairment), activity (or activity limitation), and participation (or participation restriction) [10]. According to this framework, these three levels are outcomes of interactions between health conditions, intrinsic contextual features of the individual and extrinsic contextual features of the social and physical environment (see Figure 1). Impairments of body structure or functioning are understood to be problems with the anatomical structure of the body (e.g., a missing limb) or its functioning (e.g., memory loss). Activity limitations are understood as difficulties with executing a task or action (e.g., getting dressed). Participation restrictions are problems relating to involvement in life situations (e.g., being employed). The ICF schematic (see Figure 1) is complemented by an extensive ICF Checklist, which assigned "codes" to specific dimensions of functioning and disability at three increasingly focused levels [19] (see column entitled "ICF Checklist Code" in Tables 1 and 2).

The one population-based study assessing prevalence of disability among people living with HIV was conducted in British Columbia, Canada, using an earlier version of the ICF $[12,13]$. The study revealed extraordinarily high rates of disability: over $90 \%$ of the population experienced one or more impairments, with one-third reporting over ten. Prevalence of activity limitations and participation restrictions was $80 \%$ and $93 \%$, respectively. In Southern Africa, the ICF has been used to study HIV in four studies $[7,16,17,20]$, each of which describes a diverse experience of disability among people living with HIV.

A population-based study using the ICF to evaluate the extent of disability among people living with HIV in the world's hardest hit countries would provide extremely useful data to inform health and social service needs. In the absence of such a study, however, the ICF may be used as a lens for reflecting on the results of other studies collecting data that fit within this broad conceptualization of disability. Using this framework, it is possible to examine HIV studies that are not based on the ICF, but which have investigated particular outcomes that can be located within the ICF concepts of impairment, activity and participation. As such, one could develop a preliminary picture of the disability experienced by people living with HIV by systematically reviewing various HIVrelated outcome studies using the ICF as an organizing framework.

This approach would be particularly salient in the HIV hyper-endemic countries of Botswana, Lesotho, Zimbabwe, South Africa and Swaziland where, by definition, over $15 \%$ of the country's population is HIV-positive $[1,2]$. Given the enormous burden of HIV plus the growth of access to ART in these settings, many people can expect to live longer lives but with diverse experiences of disability $[3,4]$. The policy and practice implications of the shift could be profound. As such, it is imperative to understand the extent of disability experienced by people living with HIV in high-prevalence settings.

The purpose of this article is to present the results of a scoping review that examined the extent, nature and range of disability (as conceptualized by the ICF) among people living with HIV in HIV hyper-endemic countries. By systematically reviewing data from HIV studies that may be understood within the ICF framework, we seek to demonstrate how a disability framework can complement

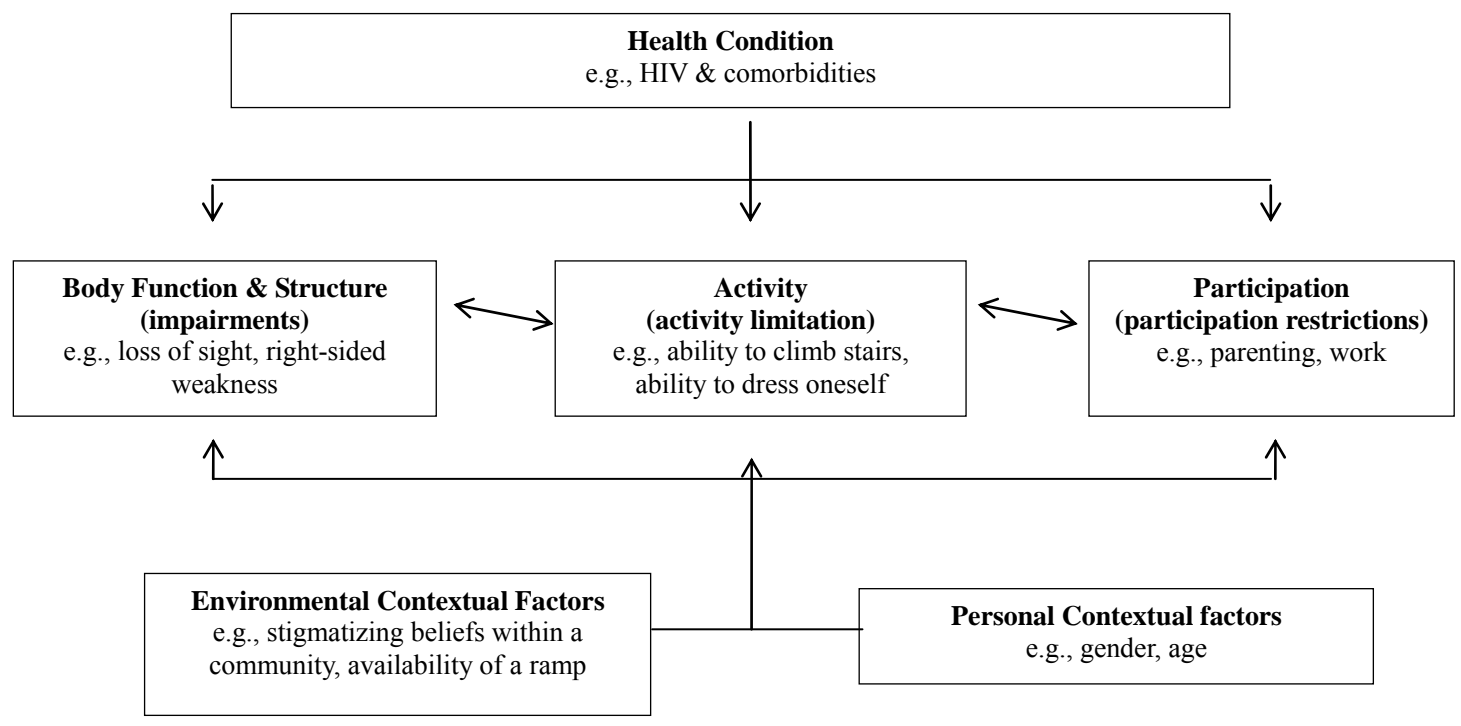

Figure 1. The World Health Organization's International Classification of Functioning, Disability and Health (ICF) with examples related to living with HIV. 
other approaches to HIV. Results can inform directions for future disability-oriented research based on the empirical gaps revealed by this analysis.

\section{Methods}

\subsection{Study Design}

We conducted a scoping study to examine the state of the literature on the extent, nature and range of disability experienced by people living with HIV in hyper-endemic countries. The study design followed the scoping study methodology outlined by Arksey \& O'Malley and further developed by Levac et al. [21,22]. This approach was complemented by the systematic review methodology described by Denyer and Tranfield $[23,24]$ to inform our use of the ICF as a lens for classifying outcomes within the HIV literature.

\subsection{Search Strategy}

This scoping study identified peer-reviewed journal articles published between January 2005 and July 2011 reporting on any disability outcome (as understood within the ICF) among people living with HIV in hyper-endemic countries. Studies were identified using keyword searches of electronic databases. The databases sourced were: EBSCOhost (including Academic Search Complete, Africa-Wide Information, Health Source, PsycARTICLES, PsycINFO, eBook Collection, Medline, and Social Science Citation Index); Science Direct; ISI Web of Science; Cochrane Library; Anthropology Index; Abridged Index Medicus (AIM); and African Journals OnLine (AJOL). The search string used synonyms and variations of the following terms: HIV/AIDS, disability, prevalence studies and HIV hyper-endemic countries. The search string for disability was developed using the first level of the ICF checklist, which identifies particular impairments, activity limitations and participation restrictions $[10,19]$. Details of the search strings for each of the databases are outlined in Additional File 1.

\subsection{Inclusion and Exclusion Criteria}

Articles were assessed according to six inclusion criteria:

1) Study participants are people living with HIV.

2) Outcomes include data on the extent of disability, as defined by the International Classification of Functioning, Disability and Health (ICF).

3) Study designs are cross-sectional, case-control, or other approaches that allow for assessment of frequency, severity and/or type of disability.

4) Studies used standardised and validated instruments

5) Study locations include one or more HIV hyperendemic country, i.e., Botswana, Lesotho, South Africa, Swaziland and/or Zimbabwe.
6) Data were collected after 2004 and published between January 1, 2005 and July 31, 2011, in order to reflect experiences of HIV since the growth of access to ART in these settings.

The search excluded newspaper articles, case studies, literature reviews, narrative papers, and papers not written in English.

\subsection{Procedure for Article Selection}

The procedure for selecting articles consisted of four steps: identification of relevant literature; screening of abstract for inclusion and exclusion criteria; assessing eligibility on the basis of full text; and, final inclusion of articles. See Figure 2 for the number of records retrieved and included in each of these steps.

Studies retrieved from the initial search were imported into a single Endnote file and duplicates were removed. Each abstract was reviewed independently by two research team members for inclusion and exclusion criteria. Full articles were downloaded for each abstract that met inclusion criteria. Hard-to-find papers were acquired by contacting the authors. All full-text articles were then reviewed again by a research team member to assess eligibility. This process resulted in 41 articles based on 38 different studies.

\subsection{Data Extraction}

Data were extracted from included studies using a data extraction sheet created for this study [21], which recorded: authors; title; year of publication; year of data (see Figure 2). Table 1 presents the measurement tools used in the included studies. Table 2 reports on how particular items in the measurement tools correspond with codes in the ICF Checklist and, thus, may be understood as reflecting disability. Table 2 first presents the items aligned with the ICF concepts of "body function and structure (impairments)", followed by "activity limitations and participations restrictions" and, lastly, according to "environmental and personal contextual factors".

Table 3 presents details of each of the 41 included articles. The final column in Table 3 presents the specific ICF dimensions of disability addressed by each study. Below we summarize findings related to the extent, nature and range of disability reported across the studies. Overall, the included studies predominately reported data at the disability level of impairment. We first present a summary of these data according to the following ICF categories: mental, sensory/perception, cardiovascular/ respiratory, digestive/metabolic/endocrine, genitourinary and reproductive, and muscle. We then summarize the lesser amount of data in the included studies related to the disability levels of activity and participation. Finally, 
Table 1. Measurement tools used in included studies that corresponded with dimensions of the ICF.

\begin{tabular}{|c|c|}
\hline Measurement tool & Included studies using each measurement tool \\
\hline ADL_Activities of Daily Living Scale & Lawler et al. 2011 \\
\hline AIDS-related Stigma Scale & Simbayi et al. 2007 \\
\hline AUDIT_Alcohol Use Disorders Identification Test & Joska et al. 2009, Myer et al. 2008 \\
\hline BDI—Beck Depression Inventory & Do et al. 2007, Lawler et al. 2011, Moosa et al. 2005 \\
\hline BPNS_-Brief Peripheral Neuropathy Score & Kagee et al. 2010, Maritz et.al 2005 \\
\hline BAVLT—Botswana Auditory Verbal Learning Test & Lawler et al. 2011 \\
\hline BSID—Bayley Scales of Infant Development, Second Edition & Ferguson et al. 2009, Jelsma 2007, Jelsma 2005 \\
\hline Carver Brief COPE & Olley et al. 2006, Olley et al. 2005 \\
\hline CESD—Centers for Epidemiological Studies Depression Scale & Myer et al. 2008, Fincham et al. 2008, Simbayi et al. 2007 \\
\hline CIDI-Composite International Diagnostic Interview & Freeman et al. 2007 \\
\hline DAP_-Goodenough Draw a Person & Zeegers et al. 2010 \\
\hline DDS—Dietary Diversity Score & Oketcha et al. 2010 \\
\hline DSC-Neuropsychological Test Battery Digit Symbol & Lawler et al. 2011 \\
\hline EPDS_Edinburgh Postnatal Depression Scale & Rochat et al. 2006 \\
\hline DSM-IV - Diagnostic and Statistical Manual of Mental Disorders IV & Schlebusch et al. 2010 \\
\hline EUROQoL_Euro Group Quality of Life Instrument & Wouters et al. 2009, Wouters 2007 \\
\hline EQ-5D_Five Domain Index of Health Status & Booyson et.al. 2007 \\
\hline GPT_-Grooved Peg Board Test & Gupta et al. 2010, Lawler et al. 2011 \\
\hline HDS-HIV Dementia Scale & Joska et al. 2009 \\
\hline HIV Stigma Scale & Petel et al. 2009 \\
\hline HR-QOL_-Health Related Quality of Life Survey & $\begin{array}{l}\text { Friend-du Preez et al. 2009, Kabore et al. } \\
\text { 2010, Nair et al. } 2009\end{array}$ \\
\hline HFIAS - Household Food Insecurity Assess Scores & Kagee et al. 2010, Oketcha et al. 2010 \\
\hline HSCL-D_-Hopkins Symptom Checklist for Depression & Kagee et al. 2010 \\
\hline HTS-Harvard Trauma Scale & Joska et al. 2009 \\
\hline HTQ_-Harvard Trauma Questionnaire & Myer et al. 2008 \\
\hline $\begin{array}{l}\text { ICF-World Health Organization International Classification } \\
\text { of Functioning, Disability and Health }\end{array}$ & Myezwa et al. 2009, Van As et al. 2009 \\
\hline IHDS—International HIV Dementia Scale & Lawler et al. 2010 \\
\hline LEC_-Life Events Checklist & Joska et al. 2009 \\
\hline Mann-Whitney Test & Rochat et al. 2006 \\
\hline MINI-Mini-International Neuropsychiatric Interview & $\begin{array}{l}\text { Fincham et al. 2008, Joska et al. 2009, Myer et al. 2008, } \\
\text { Olley et al. 2006, Olley et al. } 2005\end{array}$ \\
\hline MAS_Morisky Adherence Scale & McInerney et al. 2008 \\
\hline MOS-SS—Medical Outcomes Study Social Support Scale & McInerney et al. 2008, \\
\hline MOS-HIV QAL—Medical Outcome Study HIV and Quality of Life & Oketcha et al. 2010, Petel et al. 2009 \\
\hline MPSS-Multidimensional Scale of Perceived Social & Nair et al. 2009 \\
\hline
\end{tabular}




\section{Continued}

UNAIDS General Survey and the Department of Health Services AIDS module

OHIP—Oral Health Impact Profile

Prime-MD—Primary Care Evaluation of Mental Disorders

PNASACTG-Perceived Non-Adherence

RSRCI-Retrospective Self-Report of Childhood Inhibition

Sheehan Disability Scale

SSC-HIVrev—Sign and Symptom Checklist for Persons with HIV Disease

SCC—Subjective Cognitive Complaints Questionnaire

SSQ14-Shona Symptom Questionnaire

SF-36-Medical Outcomes Survey Short Form

SNAP-IV—Swanson, Nolan and Pelham questionnaire

SM-Suicidality Measure (adapted from Sheehan)

TNSr-Total Neuropathy Score-Reduced

UCSF CAPS HIV—University of California at San Francisco Center for AIDS Studies HIV Counseling and Testing Questionnaire

WHOQOL-HIV BREF (HRQoL) World Health Organisation's Quality of Life Instrument Module for HIV

WHO staging

WAIS-Wechsler Adult Intelligence Scale (third edition)

Medical records

Self-designed questionnaire
Gupta et al. 2010

Yengopal et al. 2008

Lawler et al. 2011(a), Lawler et al. 2011(b)

McInerney et al. 2008

Fincham et al. 2008

Olley et al. 2006

Peltzer et al. 2008

Lawler et al. 2010

Friend-du Preez et al. 2009, Petel et al. 2009, Simbayi et al. 2007

McInerney et al. 2008, Nair et al. 2009

Zeegers et al. 2010

Nair et al. 2009

Maritz et al. 2005

Patel et al. 2009

Friend-du Preez et al. 2009, Peltzer et al. 2008

Jao et al. 2011

Lawler et al. 2010

Franey 2009, Julius et al. 2011, Van Marle et al. 2009

Bhat et al. 2010, Kabore et al. 2010, Kakinami et al. 2010

Table 2. Constructs in measurement tools corresponding with ICF Checklist codes.

\begin{tabular}{|c|c|c|}
\hline ICF Checklist code & Measurement tool used in the included studies & Sample items \\
\hline \multicolumn{3}{|c|}{ Body Function and Structure (impairments) } \\
\hline \multicolumn{3}{|l|}{ b1. MENTAL FUNCTIONS } \\
\hline \multirow{2}{*}{ b110 Consciousness } & MINI-Neuro & feeling dizzy, unsteady, faint \\
\hline & SSC-HIVrev & experiencing dizziness \\
\hline \multicolumn{3}{|c|}{ b114 Orientation (time, place, person) } \\
\hline \multirow{4}{*}{ b117 Intellectual (incl. retardation } & WHODAS & understanding, cognition \\
\hline & SRQ-20 & trouble thinking \\
\hline & HIV-dementia scale & measuring constructing a cube \\
\hline & Bayleys scales & cognitive development tasks \\
\hline \multirow{4}{*}{ b130 Energy and drive functions } & SSC-HIVrev & experiencing fatigue \\
\hline & SRQ-20 & experiencing loss of energy, fatigue \\
\hline & CES-D & $\begin{array}{l}\text { being tired, exhausted, feeling tired, } \\
\text { without energy, not get going }\end{array}$ \\
\hline & HOP25/HCL & $\begin{array}{l}\text { feeling low energy, } \\
\text { everything is an effort }\end{array}$ \\
\hline
\end{tabular}




\section{Continued}

\begin{tabular}{|c|c|c|}
\hline \multirow{4}{*}{ b130 Energy and drive functions } & Hamilton Inventory & feeling physically slowed down \\
\hline & SCID-CV & experiencing low energy, tired, fatigue \\
\hline & MOS-HIV (QOL) & being tired out, enough energy, worn out \\
\hline & WHO QOL—HIV BREF & low energy \\
\hline \multirow{7}{*}{ b134 Sleep } & BDI & having sleeping problems \\
\hline & SRQ-20 & sleep badly \\
\hline & MINI-Neuro & trouble sleeping \\
\hline & CES-D & trouble sleeping \\
\hline & HOP25 / HCL & difficulty falling asleep, staying sleeping \\
\hline & Hamilton Inventory & waking up, sleep problems \\
\hline & SCID-CV & sleep problems, waking \\
\hline \multirow{9}{*}{ b140 Attention } & BDI & experiencing concentration problems \\
\hline & SNAP-ADHD & $\begin{array}{l}\text { experiencing low attention (impulsivity, } \\
\text { hyperactive behavior, restlessness, } \\
\text { day dreaming) }\end{array}$ \\
\hline & WHODAS & ability to concentrate \\
\hline & HIV-dementia scale & keeping attention \\
\hline & MINI-Neuro & $\begin{array}{l}\text { concentration, keeping attention, } \\
\text { restlessness }\end{array}$ \\
\hline & SCID-SC & thinking and concentrating problem \\
\hline & MOS-HIV (QOL) & $\begin{array}{l}\text { keeping attention, concentrating and } \\
\text { thinking }\end{array}$ \\
\hline & WHO QOL—HIV BREF & concentrating \\
\hline & SSC-HIVrev & experiencing concentration problems \\
\hline \multirow{3}{*}{ b144 Memory } & HIV-dementia scale & remembering \\
\hline & MOS-HIV (QOL) & experiencing memory, forgetting \\
\hline & SSC-HIVrev & experiencing memory loss \\
\hline \multirow{9}{*}{ b152 Emotional functions } & EQ-5D & being depressed or anxious \\
\hline & SSC-HIVrev & having fear, being upset \\
\hline & BDI & $\begin{array}{l}\text { experiencing sadness, crying, temper, } \\
\text { self-dislike }\end{array}$ \\
\hline & HIV stigma scale & being emotional affected, self-dislike \\
\hline & Edward depression scale & $\begin{array}{l}\text { stop laughing, being sad or happy, } \\
\text { blaming, being anxious, panicking, } \\
\text { feeling depressed }\end{array}$ \\
\hline & SNAP ADHD & being emotionally affected \\
\hline & WHODAS & $\begin{array}{l}\text { worried, ending life, unhappy, joy, } \\
\text { crying, no interest }\end{array}$ \\
\hline & SRQ-20 & $\begin{array}{l}\text { being worried, panicked, fear being in } \\
\text { public, feeling sad, depressed, empty, } \\
\text { bad mood, grouchy, losing joy }\end{array}$ \\
\hline & CIDI & $\begin{array}{l}\text { feeling worthless, suicidal, guilty, } \\
\text { hopeless }\end{array}$ \\
\hline
\end{tabular}




\begin{tabular}{|c|c|c|}
\hline \multirow{7}{*}{ b152 Emotional functions } & MINI-Neuro & being worried, sad \\
\hline & CES-D & $\begin{array}{l}\text { crying, lonely, nervous, fearful, lonely, } \\
\text { no interest, ending life }\end{array}$ \\
\hline & $\mathrm{HOP} 25 / \mathrm{HCL}$ & $\begin{array}{l}\text { experiencing emotions, feeling } \\
\text { depressed, moods, crying, anxious, } \\
\text { nervous }\end{array}$ \\
\hline & Hamilton Inventory & $\begin{array}{l}\text { losing interest, pleasure, feeling } \\
\text { depressed, thinking about death, feeling } \\
\text { nervous an afraid, downhearted }\end{array}$ \\
\hline & MOS-HIV (QOL) & $\begin{array}{l}\text { experiencing joy, fear, worry, } \\
\text { self-blame\& acceptance, being } \\
\text { depressed anxious }\end{array}$ \\
\hline & WHO QOL—HIV BREF & experiencing fear and worries \\
\hline & DSM IV & $\begin{array}{l}\text { experiencing fear, being afraid, scared, } \\
\text { having nightmares, being upset }\end{array}$ \\
\hline \multirow{6}{*}{ b156 Perceptual functions } & SSC-HIVrev & experiencing numbness \\
\hline & Neuropathy diagnostic tool & feeling pin and needles, numbness \\
\hline & MINI-Neuro & tingling \\
\hline & Hamilton Inventory & feeling pins and needles \\
\hline & SSC-HIVrev & having numbness and tingling \\
\hline & BPMS and TNSr & having numbness and tingling \\
\hline \multicolumn{3}{|c|}{ b164 Higher level cognitive functions } \\
\hline \multirow{2}{*}{ b167 Language } & MINI-Neuro & having trouble with language \\
\hline & Bayleys scales & understanding and expression \\
\hline \multicolumn{3}{|c|}{ b2. SENSORY FUNCTIONS AND PAIN } \\
\hline & EQ-5D & feeling pain \\
\hline & SSC-HIVrev & having headaches \\
\hline & Neuropathy diagnostic tool & feeling pain \\
\hline & SRQ-20 & feeling headache \\
\hline \multirow[t]{5}{*}{ b280 Pain } & MINI-Neuro & feeling pain \\
\hline & HOP25 / HCL & feeling headache \\
\hline & Hamilton Inventory & feeling pain \\
\hline & MOS-HIV (QOL) & feeling pain \\
\hline & WHO QOL - HIV BREF & feeling physical pain \\
\hline
\end{tabular}

b3. VOICE AND SPEECH

b4. FUNCTIONS OF THE

CARDIOVASCULAR,

HAEMATOLOGICAL,

IMMUNOLOGICAL AND

RESPIRATORY SYSTEMS

b420 Blood pressure

Medical lab tests

b5. FUNCTIONS OF THE DIGESTIVE, METABOLIC AND ENDOCRINE

SYSTEMS

b515 Digestive

SRQ-20

having digestion problems 


\section{Continued}

\begin{tabular}{|c|c|c|}
\hline b515 Digestive & SSC-HIVrev & having abdominal pain, diarrhea \\
\hline \multicolumn{3}{|l|}{ b525 Defecation } \\
\hline \multirow{4}{*}{ b530 Weight maintenance } & CIDI & losing or gaining weight \\
\hline & Hamilton Inventory & losing weight \\
\hline & SCID-CV & losing or gaining weight \\
\hline & SSC-HIVrev & gaining weight \\
\hline \multirow[t]{2}{*}{ b555 Endocrine glands (hormonal changes) } & Lab tests & having metabolic diseases \\
\hline & $\begin{array}{l}\text { BDI } \\
\text { SRQ-20 } \\
\text { CIDI }\end{array}$ & $\begin{array}{l}\text { having no appetite, experiencing } \\
\text { appetite disturbance }\end{array}$ \\
\hline \multicolumn{3}{|l|}{$\begin{array}{l}\text { b6. GENITOURINARY AND } \\
\text { REPRODUCTIVE FUNCTIONS }\end{array}$} \\
\hline \multirow{2}{*}{ b620 Urination functions } & ADL-score & having problems with bladder control \\
\hline & Medical records and lab tests & having renal impairments \\
\hline \multicolumn{3}{|l|}{$\begin{array}{l}\text { b7. NEUROMUSCULOSKELETAL AND } \\
\text { MOVEMENT RELATED FUNCTIONS }\end{array}$} \\
\hline \multirow{2}{*}{ b730 Muscle power } & WHODAS & being able to stand \\
\hline & SSC-HIVrev & having skinny arms, thump on back \\
\hline b735 Muscle tone & Hamilton Inventory & having stiff muscle \\
\hline $\begin{array}{l}\text { b8. FUNCTIONS OF THE SKIN AND } \\
\text { RELATED }\end{array}$ & SSC-HIVrev & being itchy (numbness) \\
\hline STRUCTURES & Neuropathy diagnostic tool & felling pin and needles, numbness \\
\hline Any other body functions & & \\
\hline
\end{tabular}

Activity (activity limitations) and Participation (participation restrictions)

\begin{tabular}{lll}
\hline d1. LEARNING AND APPLYING & & \\
KNOWLEDGE & WHODAS & following conversations \\
d115 Listening & WHODAS & problem solving \\
\hline & HIV-dementia scale & constructing a cube \\
d175 Solving problems & MOS-HIV (QOL) & solving problems \\
& Bayleys scales & performing cognitive development tasks \\
\hline d2. GENERAL TASKS AND DEMANDS & & \\
d3. COMMUNICATION & & \\
\hline d4. MOBILITY & & lifting objects \\
d430 Lifting and carrying objects & Neuropathy diagnostic tool & lifting \\
\hline d440 Fine hand use (picking up, grasping) & MOS-HIV (QOL) & psychomotor speed with hand \\
& Bayleys scales & conducting fine motor tasks \\
\hline
\end{tabular}


Continued

\begin{tabular}{|c|c|c|}
\hline \multirow{3}{*}{ d450 Walking } & MOS-HIV (QOL) & walking \\
\hline & EQ-5D & walking \\
\hline & Bayleys scales & conducting gross motor tasks \\
\hline \multirow{2}{*}{$\begin{array}{l}\mathbf{d} 465 \text { Moving around using equipment } \\
\text { (wheelchair, skates, etc.) }\end{array}$} & ADL-score & transferring from positions \\
\hline & WHODAS & moving around \\
\hline \multicolumn{3}{|l|}{ d5. SELF CARE } \\
\hline \multirow{2}{*}{$\begin{array}{l}\text { d510 Washing oneself (bathing, drying, } \\
\text { washing hands, etc.) }\end{array}$} & EQ-5D & having problems with washing \\
\hline & ADL-score & bathing, transfer yourself \\
\hline \multicolumn{3}{|l|}{$\begin{array}{l}\text { d520 Caring for body parts (brushing teeth, } \\
\text { shaving, grooming, etc.) }\end{array}$} \\
\hline \multirow{2}{*}{ d530 Toileting } & ADL-score & going on toilet \\
\hline & MOS-HIV (QOL) & toileting \\
\hline \multirow{4}{*}{ d540 Dressing } & EQ-5D & having problems with dressing \\
\hline & ADL-score & dressing \\
\hline & WHODAS & dressing \\
\hline & MOS-HIV (QOL) & dressing \\
\hline d550 Eating & MOS-HIV (QOL) & eating \\
\hline \multirow[t]{2}{*}{ d6. DOMESTIC LIFE } & Sheehan Disability scale & disrupted work \\
\hline & EQ-5D & $\begin{array}{l}\text { performing "usual activities" e.g. } \\
\text { housework }\end{array}$ \\
\hline \multirow{3}{*}{$\begin{array}{l}\mathbf{d 6 4 0} \text { Doing housework (cleaning house, } \\
\text { washing dishes laundry, ironing, etc.) }\end{array}$} & WHODAS & doing housework \\
\hline & MOS-HIV (QOL) & doing housework and social activities \\
\hline & WHO QOL—HIV BREF & doing daily living activities \\
\hline
\end{tabular}

\section{d8. MAJOR LIFE AREAS}

d810 Informal education

d820 School education

d830 Higher education

EQ-5D

Sheehan Disability scale

d850 Remunerative employment performing "usual activities" e.g. work

having disrupted work

doing work

working

\section{d9. COMMUNITY, SOCIAL AND} CIVIC LIFE

d910 Community Life 


\begin{tabular}{lll} 
Continued & & \\
\hline e3. SUPPORT AND RELATIONSHIPS & & emotional support from family \\
e310 Immediate family & Multi Scale of perceived Social Support & having relationships \\
\hline WHO QOL_HIV BREF & Multi Scale of perceived Social Support & having support friends \\
e320 Friends & WHO QOL_-HIV BREF & having support from friends \\
\hline $\begin{array}{l}\text { e340 Personal care providers and personal } \\
\text { assistants }\end{array}$ & Multi Scale of perceived Social Support & \\
\hline e4. ATTITUDES & & $\begin{array}{l}\text { feeling treated like an outcast, } \\
\text { experiencing rejection by people }\end{array}$ \\
\hline e460 Societal attitudes & HIV-stigma scale & \\
\hline e465 Social norms, practices and ideologies & & keeping HIV secret \\
\hline
\end{tabular}

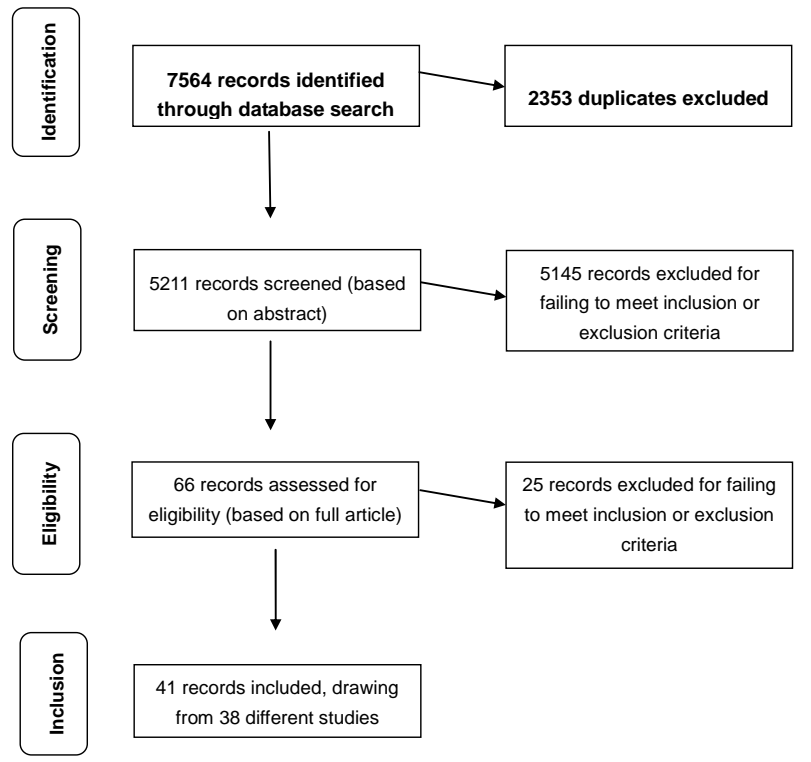

Figure 2. Flow of citations through article selection process.

we review the few studies that examined interlinkages collection; country and context (rural, peri-urban or urban); sample size; target group; sampling method; study design; concepts/constructs measured; scales/tools used; study results in general; results relevant to disability as defined in the ICF; study limitations; and authors' recommendations. Extracted data were reviewed by a second research team member to ensure quality control and consistency of extraction process. Inconsistencies were resolved through consensus.

\section{Analysis}

Once data were extracted from the 41 included articles (38 studies), we reviewed the findings for patterns related to study methods (e.g., approaches to sampling or study tools) and study results (e.g., data related to particular impairments). To analyse study results according to the ICF, we first aligned each study's findings with the corresponding ICF code. For articles that identified specific outcomes (e.g., difficulty getting dressed), we were able to directly align the outcome with the corresponding dimension of the ICF framework (e.g., ICF code "d540 Dressing"). For studies that identified research measurement tools (e.g., the Hamilton Inventory), we reviewed each tool to clarify whether and how certain items within the tool corresponded with particular dimensions of the ICF (e.g., the item "sleep problems" in the Hamilton Inventory corresponds with ICF code "b134 Sleep"). Table 1 outlines the measurement tools used in the included studies.

Table 2 illustrates how constructs in each measurement tool corresponded with the ICF Checklist codes. Once study results were organized according to the ICF, we reviewed these findings for patterns and gaps related to the extent, nature and range of disability described across the studies.

\section{Results}

\subsection{Characteristics of Included Studies}

Forty-one articles met inclusion criteria, which reported data from 38 different studies. Table 3 presents the characteristics of included studies. Of the five hyper-endemic countries considered in the scoping study, $78 \%$ of the included articles were studies conducted in South Africa (32 articles), 5 in Botswana and 1 in Zimbabwe; no studies were conducted exclusively in Lesotho or Swaziland. Two studies were conducted in more than one country, one including a site in Lesotho. 
Fifty one per cent of articles (21) took place exclusively in urban areas; $17 \%$ (7 articles) only in rural areas; $12 \%$ (5 articles) in both urban and rural settings; and $10 \%$ of studies ( 4 articles) in semi and peri-urban areas. Study setting was unclear in four articles.

In terms of study design, most studies were cross-sectional (30 articles). Three studies also used either a prospective or retrospective study design. In terms of sample size, $85 \%$ of the articles (35 articles) included more than 100 participants. Three articles $(7 \%)$ used a random sampling technique and 3 articles (7\%) used stratified sampling. Nineteen articles (47\%) used convenience sampling, 2 articles (5\%) used purposive sampling, and 14 articles (34\%) did not specify their sampling strategy. Almost all studies recruited more females than males. In $61 \%$ ( 25 articles), more than $70 \%$ of the sample was female; $20 \%$ ( 8 articles) recruited roughly equal numbers of males and female; $17 \%$ (7 articles) did not describe the sex of their participants (see Figure 3). All studies included adults except for two, which included youth below the age of eighteen $[25,26]$.

\subsection{Extent, Nature and Range of Disability}

This scoping review investigated the state of literature on disability (as conceptualized by the ICF) experienced by people living with HIV in HIV hyper-endemic countries among ICF levels.

\subsection{Impairments Related to Body Structure and Function}

Mental Function (b1): Twenty articles presented data focusing on mental functioning and an additional 8 articles presented mental functioning as part of a wider inquiry into participants' health or quality of life. Using the ICF, Myezwa et al. [25] reported impairments in mental function in $72.6 \%$ of their sample of 80 people living with HIV. They also reported energy and drive impairments in $75 \%$ and sleep impairments in $71 \%$ of the sample. Also using the ICF, van As et al. [26] reported mental functions impairments in $69 \%$ of their sample of 45 adults visiting an HIV outpatient clinic. Disorders such as depression, anxieties and post-traumatic stress disorder (PTSD) were identified in a number of studies, with percentages of the sample showing symptoms of mental health condition as follows: Kagee 38\% (depression), Myer 19\%, Moosa 56\%, Freeman 43\% (depression), Rochat 41\%, Olley 2006 48\% (depression, post-traumatic stress disorder-PTSD), Olley 2005 14.8\% (PTSD), Lawler 38\% (depression), Gupta (28\% (depression) and Finchman $13.1 \%$ (anxiety) [27-31]. Wouters et al. reported anxiety or feelings of depression in $30 \%$ of their sample [32,33]. Two studies [32-34] reported improvements in the area of emotional functions, energy and drive while being on treatment; however, one study highlighted how activity limitations continued to affect the patient's life when on ART [33].

Other mental function domains reported in the literature were consciousness, intellectual functions, memory and language. Lawler et al. (2010) reported that 38\% of their 120 participants were diagnosed with HIV-dementia. Joska et al. reported that $23.5 \%$ of their 536 participants in urban South Africa were diagnosed with HIV-associated neurocognitive disorder (HAND). Lawler et al. (2011) reported that $37 \%$ of people living with HIV were described as cognitively impaired [35-37] and Bhat et al. identified significant loss of memory in $17.9 \%$ of their sample of 168 patients at a rural health centre in South Africa [38]. The study by Lawler et al. which used a control group, reported that HIV-positive participants were more impaired on neuropsychological measures when compared to demographically-matched controls for all cognitive-motor ability areas, which included processing speed, verbal learning/memory, language, psychomotor speed, executive function, and fine motor speed [37].

Sensory and perception functions (b2): The sensory or perception functions reported most frequently were tingling or numbness. Maritz et al. reported $49 \%$ of their sample on HAART was diagnosed with peripheral neuropathy, and 30\% with severe neuropathic symptoms [39]. Data were also reported on sensory function problems and pain. Bhat et al. [38] reported that $20 \%$ of their sample experienced pain, Van As et al. [26] reveals that $71 \%$ of their sample experiencing sensory functions problems and pain, and Myezwa et al. [25] reported 83.5\% experienced sensory functions disorders. Similarly pain and discomfort were reported in $37 \%$ of participants in the study by Wouters et al. [32]. One study [40] reported on changes in ability to taste while being on treatment. No data were reported on other sensory functions, such as visual, hearing or voice impairments.

Cardiovascular and respiratory function (b4): Four articles reported data in regards to functions of the cardiovascular and respiratory system. Myezwa et al. [25] described problems in $82.5 \%$ of the participants related to the haematological, immunological and respiratory systems. Similarly, the study by van As et al. of 45 clinic patients found hypertension in 33\% of the sample, respiratory problems in $22 \%$ (which they attributed largely to TB), and at least one haematological problem in $96 \%$ of the sample. High blood pressure was also recorded Maritz et al., and problems with breathing and breathlessness in $13 \%$ of the sample in Bhat et al.

Digestive, metabolic and endocrine function (b5): Six studies reported data on impairments in digestive, metabolic or endocrine function, on or off treatment. Data were presented regarding increase or loss in weight as well as diagnostic of obesity [38,41,42]. Additionally, 
Table 3. Characteristics of included studies.

\begin{tabular}{|c|c|c|c|c|c|c|}
\hline Author & Title & $\begin{array}{l}\text { Study } \\
\text { site }\end{array}$ & Study design & Population & $\begin{array}{c}\text { Study } \\
\text { Instruments }\end{array}$ & ICF Checklist Code \\
\hline $\begin{array}{l}\text { Bhat et al. } \\
\text { (2010) }\end{array}$ & $\begin{array}{l}\text { Factors associated with } \\
\text { poor adherence to antiret- } \\
\text { roviral therapy in patients } \\
\text { attending a rural health } \\
\text { centre in South Africa }\end{array}$ & $\begin{array}{l}\text { South } \\
\text { Africa: } \\
\text { rural }\end{array}$ & Cross-sectional & $\begin{array}{l}\mathrm{N}=168 \text { PLHIV on ARV } \\
60 \% \text { females }\end{array}$ & $\begin{array}{l}\text { Self-designed } \\
\text { pre-structured } \\
\text { questionnaires }\end{array}$ & $\begin{array}{l}\text { - } \text { B130: "side effects", fatigue } \\
\text { - } \text { B144: memory } \\
\text { - } \text { B280: pain } \\
\text { - } \text { S120 or B156: tingling } \\
\text { - } \text { B530: weight loss } \\
\text { - } \text { B440: breathing problems } \\
\text { - } \text { B152: depression, sadness, } \\
\text { - } \text { Bnxiety b152 } \\
\text { - } \text { B8: skin rash and hair changes }\end{array}$ \\
\hline $\begin{array}{l}\text { Booysen et } \\
\text { al. (2007) }\end{array}$ & $\begin{array}{l}\text { The heart in HAART: } \\
\text { quality of life of patients } \\
\text { enrolled in the } \\
\text { public-sector } \\
\text { antiretroviral } \\
\text { treatment } \\
\text { programme in the Free } \\
\text { State Province of South } \\
\text { Africa }\end{array}$ & $\begin{array}{l}\text { South } \\
\text { Africa: } \\
\text { rural }\end{array}$ & $\begin{array}{l}\text { Case-control } \\
\text { study }\end{array}$ & $\begin{array}{l}\mathrm{N}=371 \text { PLHIV waiting for } \\
\text { ART and ART Almost } 2 / 3 \\
\text { females }\end{array}$ & EQ-5D & $\begin{array}{l}\text { - } \quad \text { D4: quality of life } \\
\text { - } \quad \text { B: mobility (not specified) } \\
\text { - } \quad \text { D5: self care (not specified) }\end{array}$ \\
\hline $\begin{array}{l}\text { Do et al. } \\
\text { (2010) }\end{array}$ & $\begin{array}{l}\text { Psychosocial Factors } \\
\text { Affecting } \\
\text { Medication } \\
\text { Adherence among HIV-1 } \\
\text { Infected Adults Receiving } \\
\text { Combination } \\
\text { Antiretroviral } \\
\text { Therapy (cART) in } \\
\text { Botswana }\end{array}$ & $\begin{array}{l}\text { Bot- } \\
\text { swana: } \\
\text { urban }\end{array}$ & Cross-sectional & $\begin{array}{l}\mathrm{N}=300 \text { PLHIV on ART } \\
76.3 \% \text { females }\end{array}$ & BDI & $\begin{array}{l}\text { - B152: alcohol abuse and } \\
\text { depression } \\
\text { - B144: forgetting ART }\end{array}$ \\
\hline $\begin{array}{l}\text { Ferguson } \\
\text { et al. } \\
(2009)\end{array}$ & $\begin{array}{l}\text { The prevalence of motor } \\
\text { delay among HIV-Infected } \\
\text { children living in cape } \\
\text { Town, South Africa Also } \\
\text { Jelsma, J. \& Ferguson, G., } \\
\text { 2007, Motor } \\
\text { Development in Children } \\
\text { Living within Resource } \\
\text { Poor Areas of } \\
\text { Western Cape }\end{array}$ & $\begin{array}{l}\text { South } \\
\text { Africa: } \\
\text { urban }\end{array}$ & $\begin{array}{l}\text { Disability } \\
\text { prevalence }\end{array}$ & $\begin{array}{l}\mathrm{N}=86(\mathrm{HIV} \text { infected } \\
\text { children and non-infected } \\
\text { children }\end{array}$ & BSID & $\begin{array}{l}\text { - B } 7 \text { and d4: motor development } \\
\text { delay }\end{array}$ \\
\hline $\begin{array}{l}\text { Fincham } \\
\text { et al. } \\
(2008)\end{array}$ & $\begin{array}{l}\text { The relationship between } \\
\text { behavioural inhibition, } \\
\text { anxiety disorders, } \\
\text { depression and CD4 } \\
\text { counts in HIV-Positive } \\
\text { adults: a cross-sectional } \\
\text { controlled study }\end{array}$ & $\begin{array}{l}\text { South } \\
\text { Africa: } \\
\text { rural }\end{array}$ & Cross-sectional & $\begin{array}{l}\mathrm{N}=456 \text { PLHIV } \\
75 \% \text { females }\end{array}$ & $\begin{array}{l}\text { RSRCI, CES-D, } \\
\text { MINI }\end{array}$ & $\begin{array}{l}\text { B152: GAD, depression and } \\
\text { PTSD } \\
\text { D7: social fears associated to } \\
\text { depression (not specified) }\end{array}$ \\
\hline $\begin{array}{l}\text { Franey et } \\
\text { al. (2009) }\end{array}$ & $\begin{array}{l}\text { Renal Impairment in a } \\
\text { Rural African } \\
\text { Antiretroviral } \\
\text { Programme }\end{array}$ & $\begin{array}{l}\text { South } \\
\text { Africa: } \\
\text { rural }\end{array}$ & $\begin{array}{l}\text { Retrospective } \\
\text { review and } \\
\text { prospective } \\
\text { study }\end{array}$ & $\begin{array}{l}\mathrm{N}=2189 \text { patients on } \mathrm{ARV} \\
68.8 \% \text { females }\end{array}$ & $\begin{array}{l}\text { Review of medi- } \\
\text { cal } \\
\text { records }\end{array}$ & $\begin{array}{l}\text { - } \quad \text { B8: skin irritations } \\
\text { - B620: renal dysfunction }\end{array}$ \\
\hline $\begin{array}{l}\text { Freeman } \\
\text { et al. } \\
(2007)\end{array}$ & $\begin{array}{l}\text { Factors Associated with } \\
\text { Prevalence of Mental } \\
\text { Disorder in People Living } \\
\text { with HIV/AIDS in South } \\
\text { Africa. }\end{array}$ & $\begin{array}{l}\text { South } \\
\text { Africa: } \\
\text { rural }\end{array}$ & Cross-sectional & $\begin{array}{l}\mathrm{N}=900 \text { PLHIV some on } \\
\text { ART } \\
74 \% \text { females }\end{array}$ & $\begin{array}{l}\text { CIDI, } \\
\text { Point-prevalence }\end{array}$ & $\begin{array}{l}\text { B152: mental health disorder } \\
\text { (mainly depression) } \\
\text { D7: discrimination by } \\
\text { community/ family and } \\
\text { isolation }\end{array}$ \\
\hline
\end{tabular}


Continued

\begin{tabular}{|c|c|c|c|c|c|c|}
\hline $\begin{array}{l}\text { Friend-du } \\
\text { Preez et al. } \\
\text { (2009) }\end{array}$ & $\begin{array}{l}\text { HIV Symptoms and } \\
\text { Health-Related } \\
\text { Quality of Life Prior } \\
\text { to Initiation of } \\
\text { HAART in a Sample } \\
\text { of HIV-Positive } \\
\text { South Africans }\end{array}$ & $\begin{array}{l}\text { South } \\
\text { Africa: rural }\end{array}$ & Cross-sectional & $\begin{array}{l}\mathrm{N}=612 \text { PLHIV prior } \\
\text { HAART } \\
70.3 \% \text { females }\end{array}$ & $\begin{array}{l}\text { SSC-HIVrev, } \\
\text { WHOQOL-HIV } \\
\text { BREF (HRQoL) }\end{array}$ & $\begin{array}{l}\text { - } \text { B530: weight loss } \\
\text { - } \text { B8: dry mouth } \\
\text { - } \text { B280: headaches } \\
\text { - } \text { B144: memory loss } \\
\text { - B130: weakness } \\
\text { - } \text { B280: painful joints }\end{array}$ \\
\hline $\begin{array}{l}\text { Gupta et } \\
\text { al. (2010) }\end{array}$ & $\begin{array}{l}\text { Depression and HIV } \\
\text { in Botswana: A } \\
\text { population-based } \\
\text { study on } \\
\text { gender-specific } \\
\text { socioeconomic and } \\
\text { behavioral correlates }\end{array}$ & $\begin{array}{l}\text { Botswana: } \\
\text { rural }\end{array}$ & Cross-sectional & $\begin{array}{l}\mathrm{N}=1168 \text { PLHIV } \\
\text { Not known gender } \\
\text { distribution }\end{array}$ & $\begin{array}{l}\text { HSCL-D, UNAIDS } \\
\text { General Survey and } \\
\text { the Department of } \\
\text { Health Services } \\
\text { AIDS module }\end{array}$ & $\begin{array}{l}\text { - B152: emotional e.g. depression } \\
\text { - D7 and D770: lack of control in } \\
\text { sexual relationships and stigma }\end{array}$ \\
\hline $\begin{array}{l}\text { Jao et al. } \\
\text { (2011) }\end{array}$ & $\begin{array}{l}\text { Factors associated } \\
\text { with decreased } \\
\text { kidney function in } \\
\text { HIV-infected adults } \\
\text { enrolled in the } \\
\text { MTCT-Plus } \\
\text { Initiative in } \\
\text { Sub-Saharan Africa }\end{array}$ & $\begin{array}{l}\text { Multicounty } \\
\text { including, } \\
\text { South } \\
\text { Africa }\end{array}$ & $\begin{array}{l}\text { Prevalence } \\
\text { study }\end{array}$ & $\begin{array}{l}\mathrm{N}=2495 \text { PLHIV on } \\
\mathrm{ART}>70 \% \text { females }\end{array}$ & $\begin{array}{l}\text { WHO staging, CD4 } \\
\text { cell count, } \\
\text { Cockcroft-Gault } \\
\text { (CG) equations for } \\
\text { creatinine clearance, } \\
\text { Diet in Renal Disease } \\
\text { Equation (MDRD) } \\
\text { and CKD } \\
\text { Epidemiology } \\
\text { Collaboration } \\
\text { (CKD-EPI) }\end{array}$ & - B620: Urination functions \\
\hline $\begin{array}{l}\text { Jelsma et } \\
\text { al. (2005) }\end{array}$ & $\begin{array}{l}\text { An investigation into } \\
\text { the health-related } \\
\text { quality of life of } \\
\text { individuals living } \\
\text { with HIV who are } \\
\text { receiving HAART }\end{array}$ & $\begin{array}{l}\text { South } \\
\text { Africa: } \\
\text { urban }\end{array}$ & Cross-sectional & $\begin{array}{l}\mathrm{N}=83 \text { PLHIV on } \\
\text { HAART } \\
74.5 \% \text { females }\end{array}$ & EQ-5D & $\begin{array}{l}\text { - B280: pain, discomfort } \\
\text { - } \quad \text { B152: emotional e.g. anxiety and } \\
\text { depression } \\
\text { - } \quad \text { D4 mobility } \\
\text { - } \quad \text { D5: self care activities }\end{array}$ \\
\hline $\begin{array}{l}\text { Joska et } \\
\text { al. (2009) }\end{array}$ & $\begin{array}{l}\text { Clinical Correlates of } \\
\text { HIV-Associated } \\
\text { Neurocognitive } \\
\text { Disorders (HAND) } \\
\text { in South Africa }\end{array}$ & $\begin{array}{l}\text { South } \\
\text { Africa (SA): } \\
\text { urban }\end{array}$ & Cross-sectional & $\begin{array}{l}\mathrm{N}=536 \text { PLHIV } \\
73.3 \% \text { females }\end{array}$ & $\begin{array}{l}\text { HDS, MINI, AUDIT, } \\
\text { HTS, LEC }\end{array}$ & $\begin{array}{l}\text { - } \mathrm{B} 114, \mathrm{~B} 117, \mathrm{~B} 140, \mathrm{~B} 144: \mathrm{HAND} \\
\text { - } \mathrm{B} 152: \mathrm{PTSD}\end{array}$ \\
\hline $\begin{array}{l}\text { Julius et } \\
\text { al. (2011) }\end{array}$ & $\begin{array}{l}\text { The Burden of } \\
\text { Metabolic Diseases } \\
\text { Amongst HIV } \\
\text { Positive Patients on } \\
\text { HAART Attending } \\
\text { The Johannesburg } \\
\text { Hospital }\end{array}$ & $\begin{array}{l}\text { South } \\
\text { Africa: } \\
\text { urban }\end{array}$ & Cross-sectional & $\begin{array}{l}\mathrm{N}=304 \text { PLHIV on } \\
\mathrm{ART}>1 \text { year) } \\
78 \% \text { females }\end{array}$ & $\begin{array}{l}\text { Patient clinical } \\
\text { records, blood tests } \\
\text { and anthropometric } \\
\text { measurements. }\end{array}$ & $\begin{array}{l}\text { - B4: metabolic diseases (diabetes, } \\
\text { hypertension...) }\end{array}$ \\
\hline $\begin{array}{l}\text { Kabore et } \\
\text { al. (2010) }\end{array}$ & $\begin{array}{l}\text { The Effect of } \\
\text { Community-Based } \\
\text { Support Services on } \\
\text { Clinical Efficacy and } \\
\text { Health-Related } \\
\text { Quality of Life in } \\
\text { HIV/AIDS Patients } \\
\text { in Resource-Limited } \\
\text { Settings in } \\
\text { Sub-Saharan Africa }\end{array}$ & $\begin{array}{l}\text { Cross-count } \\
\text { ry incl. } \\
\text { South } \\
\text { Africa, } \\
\text { Lesotho and } \\
\text { Botswana }\end{array}$ & $\begin{array}{l}\text { Observational } \\
\text { cohort study }\end{array}$ & $\begin{array}{l}\mathrm{N}=377 \text { PLHIV on } \\
\mathrm{ART} \\
72 \% \text { females }\end{array}$ & $\begin{array}{l}\text { Self designed } \\
\text { questionnaires, } \\
\text { HRQOL }\end{array}$ & 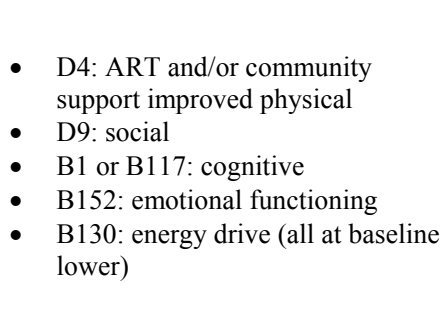 \\
\hline $\begin{array}{l}\text { Kagee et } \\
\text { al. (2010) }\end{array}$ & $\begin{array}{l}\text { Psychological } \\
\text { Distress among } \\
\text { Persons Living with } \\
\text { HIV, Hypertension, } \\
\text { and Diabetes }\end{array}$ & $\begin{array}{l}\text { South } \\
\text { Africa: } \\
\text { semi-urban }\end{array}$ & Cross-sectional & $\begin{array}{l}\mathrm{N}=124 \text { PLHIV } \\
\text { receiving treatment } \\
\text { for diabetes or } \\
\text { hypertension, } 79 \% \\
\text { females }\end{array}$ & HSCL-25 & - B152: emotional distress \\
\hline $\begin{array}{l}\text { Kagee et } \\
\text { al. (2010) }\end{array}$ & $\begin{array}{l}\text { Symptoms of } \\
\text { Depression and } \\
\text { Anxiety among a } \\
\text { Sample of South } \\
\text { African Patients } \\
\text { Living with HIV }\end{array}$ & $\begin{array}{l}\text { South } \\
\text { Africa: } \\
\text { semi-urban }\end{array}$ & $\begin{array}{l}\text { Prevalence } \\
\text { study }\end{array}$ & $\begin{array}{l}\mathrm{N}=85 \text { PLHIV some } \\
\text { on ART } \\
75.3 \% \text { females }\end{array}$ & HSCL-25, BDI & - B152: depression and anxiety \\
\hline
\end{tabular}




\section{Continued}

\begin{tabular}{|c|c|c|c|c|c|c|}
\hline $\begin{array}{l}\text { Kakinami } \\
\text { et al. } \\
\text { (2010) }\end{array}$ & $\begin{array}{l}\text { The Impact of } \\
\text { Highly Active } \\
\text { Antiretroviral } \\
\text { Therapy on } \\
\text { Activities of Daily } \\
\text { Living in } \\
\text { HIV-Infected Adults } \\
\text { in South Africa }\end{array}$ & $\begin{array}{l}\text { South } \\
\text { Africa: } \\
\text { urban and } \\
\text { rural }\end{array}$ & Cross sectional & $\begin{array}{l}\mathrm{N}=4328 \text { PLHIV } \\
71 \%-78 \% \text { women }\end{array}$ & $\begin{array}{l}\text { Self developed } \\
\text { questionnaires }\end{array}$ & - D4-6 activity assistance needs \\
\hline $\begin{array}{l}\text { Lawler et } \\
\text { al. (2010) }\end{array}$ & $\begin{array}{l}\text { Neurocognitive } \\
\text { impairment among } \\
\text { HIV-positive } \\
\text { individuals in } \\
\text { Botswana: a pilot } \\
\text { study }\end{array}$ & $\begin{array}{l}\text { Botswana: } \\
\text { urban }\end{array}$ & Cross-sectional & $\begin{array}{l}\mathrm{N}=120 \text { PLHIV } \\
50 \% \text { females }\end{array}$ & $\begin{array}{l}\text { IHDS, Verbal } \\
\text { Learning Test, WAIS } \\
\text { Digit Symbol } \\
\text { Coding, Mood } \\
\text { Module of the } \\
\text { primary care } \\
\text { evaluation of mental } \\
\text { disorders, Activities } \\
\text { of Daily Living } \\
\text { Scale, SCC }\end{array}$ & - B117: dementia \\
\hline $\begin{array}{l}\text { Lawler et } \\
\text { al. (2011) }\end{array}$ & $\begin{array}{l}\text { Depression among } \\
\text { HIV-positive } \\
\text { individuals in } \\
\text { Botswana: a } \\
\text { behavioral } \\
\text { surveillance }\end{array}$ & $\begin{array}{l}\text { Botswana: } \\
\text { urban }\end{array}$ & $\begin{array}{l}\text { Mental health } \\
\text { prevalence }\end{array}$ & $\begin{array}{l}\mathrm{N}=120 \text { PLHIV } \\
\text { (random) } \\
50 \% \text { women }\end{array}$ & $\begin{array}{l}\text { BDI-FS, Mood } \\
\text { Module (MM) of } \\
\text { Prime-MD, ADL }\end{array}$ & - B152: emotional e.g. depression \\
\hline $\begin{array}{l}\text { Maritz et } \\
\text { al. (2010) }\end{array}$ & $\begin{array}{l}\text { HIV Neuropathy In } \\
\text { South Africans: } \\
\text { Frequency, } \\
\text { Characteristics, And } \\
\text { Risk Factors }\end{array}$ & $\begin{array}{l}\text { South } \\
\text { Africa: } \\
\text { urban }\end{array}$ & Cross-sectional & $\begin{array}{l}\mathrm{N}=598 \text { PLHIV on } \\
\text { ART } \\
76 \% \text { females }\end{array}$ & $\begin{array}{l}\text { BPNS, TNSr, CD4 } \\
\text { counts, ART status }\end{array}$ & $\begin{array}{l}\text { - } \quad \text { B156 or B7: neuropathy } \\
\text { - B420: blood pressure }\end{array}$ \\
\hline $\begin{array}{l}\text { Mclnerne } \\
\text { y et al. } \\
(2008)\end{array}$ & $\begin{array}{l}\text { Quality of life and } \\
\text { physical function in } \\
\text { HIV-infected } \\
\text { individuals receiving } \\
\text { antiretroviral therapy } \\
\text { in KwaZulu-Natal, } \\
\text { South Africa }\end{array}$ & $\begin{array}{l}\text { South } \\
\text { Africa: area } \\
\text { not } \\
\text { described }\end{array}$ & $\begin{array}{l}\text { Descriptive } \\
\text { exploratory } \\
\text { design }\end{array}$ & $\begin{array}{l}\mathrm{N}=149 \text { PLHIV on } \\
\text { ART } \\
\mathrm{N}=95 \text { females }\end{array}$ & $\begin{array}{l}\text { MOS-SSS, SF-36, } \\
\text { MOS-SF36HS, } \\
\text { PNASACTG, MAS }\end{array}$ & $\begin{array}{ll}\text { - } & \text { D4: mobility } \\
\text { - } & \text { D2: general tasks and demands } \\
\text { - } & \text { E3: social support }\end{array}$ \\
\hline $\begin{array}{l}\text { Moosa et } \\
\text { al. (2005) }\end{array}$ & $\begin{array}{l}\text { HIV in South Africa } \\
\text { - depression and } \\
\text { CD4 count }\end{array}$ & $\begin{array}{l}\text { South } \\
\text { Africa }\end{array}$ & $\begin{array}{l}\text { Prevalence of } \\
\text { depression }\end{array}$ & $\begin{array}{l}\mathrm{N}=41 \text { PLHIV } \\
71 \% \text { females }\end{array}$ & $\begin{array}{l}\text { BDI - Beck } \\
\text { Depression Inventor, } \\
\text { CD4 count test }\end{array}$ & - B152: emotional e.g. depression \\
\hline $\begin{array}{l}\text { Myer et al. } \\
\text { (2008) }\end{array}$ & $\begin{array}{l}\text { Common Mental } \\
\text { Disorders among } \\
\text { HIV-Infected } \\
\text { Individuals in South } \\
\text { Africa: Prevalence, } \\
\text { Predictors, and } \\
\text { Validation of Brief } \\
\text { Psychiatric Rating } \\
\text { Scales }\end{array}$ & $\begin{array}{l}\text { South } \\
\text { Africa: } \\
\text { semi-urban }\end{array}$ & $\begin{array}{l}\text { Cross-sectional } \\
\text { study }\end{array}$ & $\begin{array}{l}\mathrm{N}=465 \text { PLHIV with } \\
>24 \text { on the MMSE } \\
75 \% \text { females }\end{array}$ & $\begin{array}{l}\text { MINI, CES-D, HTQ, } \\
\text { AUDIT }\end{array}$ & $\begin{array}{l}\text { - B152: depression PTSD and alcohol } \\
\text { dependence }\end{array}$ \\
\hline $\begin{array}{l}\text { Myezwa et } \\
\text { al. (2009) }\end{array}$ & $\begin{array}{l}\text { Assessment of } \\
\text { HIV-positive } \\
\text { in-patients using the } \\
\text { International } \\
\text { Classification of } \\
\text { Functioning, } \\
\text { Disability and Health } \\
\text { (ICF) at Chris Hani } \\
\text { Baragwanath } \\
\text { Hospital, } \\
\text { Johannesburg }\end{array}$ & $\begin{array}{l}\text { South } \\
\text { Africa: } \\
\text { urban }\end{array}$ & $\begin{array}{l}\text { Cross-sectional } \\
\text { study with ICF } \\
\text { checklist }\end{array}$ & $\begin{array}{l}\mathrm{N}=80 \text { PLHIV some } \\
\text { on ART } \\
\text { Gender not } \\
\text { specified }\end{array}$ & ICF checklist & - All ICF domains \\
\hline
\end{tabular}


Continued

\begin{tabular}{|c|c|c|c|c|c|c|}
\hline $\begin{array}{l}\text { Nair et al. } \\
\text { (2009) }\end{array}$ & $\begin{array}{l}\text { Psychological } \\
\text { Well-Being and } \\
\text { Health Related } \\
\text { Quality of Life } \\
\text { among a Group of } \\
\text { Low-Income Women } \\
\text { Living with } \\
\text { HIV/AIDS in South } \\
\text { Africa }\end{array}$ & $\begin{array}{l}\text { South } \\
\text { Africa: } \\
\text { urban }\end{array}$ & $\begin{array}{l}\text { Cross-sectional } \\
\text { study }\end{array}$ & $\begin{array}{l}\mathrm{N}=133 \text { PLHIV } \\
>70 \% \text { females }\end{array}$ & $\begin{array}{l}\text { MPSS, SM, HRQOL, } \\
\text { SF-36 }\end{array}$ & $\begin{array}{l}\text { - } \text { D4: physical functioning } \\
\text { - } \text { B130: vitality } \\
\text { - } \text { B152: mental health } \\
\text { - } \text { B280: bodily pain } \\
\text { - } \quad \text { D8: normal work } \\
\text { - } \\
\text { E3: perceived social support }\end{array}$ \\
\hline $\begin{array}{l}\text { Oketcha et } \\
\text { al. (2010) }\end{array}$ & $\begin{array}{l}\text { Too little, too late: } \\
\text { Comparison of } \\
\text { nutritional status and } \\
\text { quality of life of } \\
\text { nutrition care and } \\
\text { support recipient and } \\
\text { non-recipients } \\
\text { among HIV-positive } \\
\text { adults in } \\
\text { KwaZulu-Natal. }\end{array}$ & $\begin{array}{l}\text { South } \\
\text { Africa: } \\
\text { semi-urban }\end{array}$ & $\begin{array}{l}\text { Cross-sectional } \\
\text { study }\end{array}$ & $\begin{array}{l}\mathrm{N}=300 \text { PLHIV, } 97 \\
\text { in intervention } \\
\mathrm{N}=252 \text { females }\end{array}$ & $\begin{array}{l}\text { DDS, HFIAS, } \\
\text { malnutrition: } \\
\text { assessment screening } \\
\text { tool for HIV-positive } \\
\text { adults, nutritional } \\
\text { status: } \\
\text { Anthropometry with } \\
\text { ISAK and BMI, } \\
\text { QAL: MOS-HIV }\end{array}$ & $\begin{array}{l}\text { - B530: obesity } \\
\text { - B8: skin infection } \\
\text { D5: self care }\end{array}$ \\
\hline $\begin{array}{l}\text { Olley et al. } \\
\text { (2006) }\end{array}$ & $\begin{array}{l}\text { Persistence of } \\
\text { psychiatric disorders } \\
\text { in a cohort of } \\
\text { HIV/AIDS patients } \\
\text { in South Africa: A } \\
\text { 6-month follow-up } \\
\text { study }\end{array}$ & $\begin{array}{l}\text { South } \\
\text { Africa: } \\
\text { urban }\end{array}$ & $\begin{array}{l}\text { Cross-sectional } \\
\text { study }\end{array}$ & $\begin{array}{l}\mathrm{N}=65 \text { PLHIV } \\
\mathrm{N}=56 \text { females }\end{array}$ & $\begin{array}{l}\text { MINI, INI, Carver } \\
\text { Brief COPE, the } \\
\text { Sheehan Disability } \\
\text { Scale and exposure } \\
\text { to negative life } \\
\text { events and risk } \\
\text { behaviors }\end{array}$ & $\begin{array}{l}\text { - } \text { B152: depression and PTSD } \\
\text { - } \text { D8: work } \\
\text { - } \text { D9: social } \\
\text { - } \text { D7: family life }\end{array}$ \\
\hline $\begin{array}{l}\text { Olley et al. } \\
\text { (2005) }\end{array}$ & $\begin{array}{l}\text { Post-traumatic stress } \\
\text { disorder among } \\
\text { recently diagnosed } \\
\text { patients with } \\
\text { HIV/AIDS in South } \\
\text { Africa }\end{array}$ & $\begin{array}{l}\text { South } \\
\text { Africa: } \\
\text { urban }\end{array}$ & $\begin{array}{l}\text { Cross-sectional } \\
\text { study }\end{array}$ & $\begin{array}{l}\mathrm{N}=149 \text { PLHIV } \\
\mathrm{N}=105 \text { females }\end{array}$ & $\begin{array}{l}\text { MINI, the Carver } \\
\text { Brief COPE coping } \\
\text { scale and the } \\
\text { Sheehan Disability } \\
\text { Scale, previous } \\
\text { exposures to trauma } \\
\text { and past risk } \\
\text { behaviours }\end{array}$ & $\begin{array}{l}\text { - } \text { B152: emotional e.g. depression } \\
\text { and PTSD } \\
\text { - } \quad \text { D8: work } \\
\text { - } \quad \text { D9: social } \\
\text { - } \quad \text { D7: family life }\end{array}$ \\
\hline $\begin{array}{l}\text { Patel et al. } \\
\text { (2009) }\end{array}$ & $\begin{array}{l}\text { Quality of life, } \\
\text { psychosocial health, } \\
\text { and antiretroviral } \\
\text { therapy among } \\
\text { HIV-positive women } \\
\text { in Zimbabwe }\end{array}$ & $\begin{array}{l}\text { Zimbabwe: } \\
\text { urban }\end{array}$ & $\begin{array}{l}\text { Cross-sectional } \\
\text { study }\end{array}$ & $\begin{array}{l}\mathrm{N}=200 \text { PLHIV on } \\
\mathrm{ART} \\
>70 \% \text { females }\end{array}$ & $\begin{array}{l}\text { HIV Stigma Scale, } \\
\text { UCSF CAPS HIV } \\
\text { Counselling and } \\
\text { Testing, SSQ14, } \\
\text { MOS-HIV QOL }\end{array}$ & $\begin{array}{l}\text { - B130: general health perception/ } \\
\text { vitality } \\
\text { - } \quad \text { D4: physical functioning } \\
\text { - B280: bodily pain } \\
\text { - B152: mental health }\end{array}$ \\
\hline $\begin{array}{l}\text { Peltzer et } \\
\text { al. (2008) }\end{array}$ & $\begin{array}{l}\text { Health-related } \\
\text { quality of life in a } \\
\text { sample of } \\
\text { HIV-infected South } \\
\text { Africans }\end{array}$ & $\begin{array}{l}\text { South } \\
\text { Africa: rural }\end{array}$ & $\begin{array}{l}\text { Prevalence } \\
\text { study }\end{array}$ & $\begin{array}{l}\mathrm{N}=607 \text { PLHIV } \\
78 \% \text { females }\end{array}$ & $\begin{array}{l}\text { SSC-HIVrev; } \\
\text { WHOQOL-HIV } \\
\text { BREF, HIV } \\
\text { symptoms and } \\
\text { medical variables, } \\
\text { socio-economic } \\
\text { variables }\end{array}$ & $\begin{array}{l}\text { B130, B280, B152: low energy, } \\
\text { pain } \\
\text { E1, D9: low environmental domain } \\
\text { decreases participation (transport, } \\
\text { participation accessibility) }\end{array}$ \\
\hline $\begin{array}{l}\text { Rochat et } \\
\text { al. (2006) }\end{array}$ & $\begin{array}{l}\text { Depression among } \\
\text { pregnant rural South } \\
\text { African women } \\
\text { undergoing HIV } \\
\text { testing }\end{array}$ & $\begin{array}{l}\text { South } \\
\text { Africa: rural }\end{array}$ & $\begin{array}{l}\text { Depression } \\
\text { prevalence } \\
\text { study }\end{array}$ & $\begin{array}{l}\mathrm{N}=242 \text { pregnant } \\
\text { women }\end{array}$ & $\begin{array}{l}\text { EPDS, } \\
\text { Mann-Whitney test }\end{array}$ & $\begin{array}{l}\text { - } \quad \text { B152: depression } \\
\text { - } \quad \text { D9 perception of discrimination } \\
\text { - } \quad \text { E1: health care and finance }\end{array}$ \\
\hline $\begin{array}{l}\text { Schle- } \\
\text { busch et } \\
\text { al. (2010) }\end{array}$ & $\begin{array}{l}\text { HIV-infection as a } \\
\text { self-reported risk } \\
\text { factor for attempted } \\
\text { suicide in South } \\
\text { Africa }\end{array}$ & $\begin{array}{l}\text { South } \\
\text { Africa: } \\
\text { urban }\end{array}$ & $\begin{array}{l}\text { Quantitative } \\
\text { study }\end{array}$ & $\begin{array}{l}\mathrm{N}=112 \text { PLHIV who } \\
\text { committed suicide, } \\
\text { gender not specified }\end{array}$ & $\begin{array}{l}\text { Self designed against } \\
\text { DSM-IV-TR12 } \\
\text { criteria }\end{array}$ & - B152: emotional e.g. depression \\
\hline $\begin{array}{l}\text { Simbayi et } \\
\text { al. (2007) }\end{array}$ & $\begin{array}{l}\text { Internalized stigma, } \\
\text { discrimination, and } \\
\text { depression among } \\
\text { men and women } \\
\text { living with } \\
\text { HIV/AIDS in Cape } \\
\text { Town, South Africa }\end{array}$ & $\begin{array}{l}\text { South } \\
\text { Africa: } \\
\text { urban }\end{array}$ & Survey & $\begin{array}{l}\mathrm{N}=1063 \text { PLHIV } \\
\mathrm{N}=643 \text { females }\end{array}$ & $\begin{array}{l}\text { AIDS related Stigma } \\
\text { scale, self developed } \\
\text { discrimination scale, } \\
\text { CESD, SSQ self } \\
\text { designed substance } \\
\text { abuse questionnaire }\end{array}$ & $\begin{array}{l}\text { - B152: internalized AIDS stigma } \\
\text { and depression (cognitive and } \\
\text { affective [CESD] } \\
\text { - } \quad \text { E4: HIV discrimination } \\
\text { - } \quad \text { E3: social support } \\
\text { - } \quad \text { B152": substance abuse: alcohol } \\
\text { abuse and drug abuse }\end{array}$ \\
\hline
\end{tabular}




\section{Continued}

\begin{tabular}{|c|c|c|c|c|c|c|}
\hline $\begin{array}{l}\text { Van as et } \\
\text { al. (2009) }\end{array}$ & $\begin{array}{l}\text { The international } \\
\text { classification of } \\
\text { function disability } \\
\text { and health (ICF) in } \\
\text { adults visiting the } \\
\text { HIV outpatient clinic } \\
\text { at a regional hospital } \\
\text { in Johannesburg, } \\
\text { South Africa }\end{array}$ & $\begin{array}{l}\text { South } \\
\text { Africa: } \\
\text { urban }\end{array}$ & $\begin{array}{l}\text { Cross-sectional } \\
\text { descriptive } \\
\text { study }\end{array}$ & $\begin{array}{l}\mathrm{N}=45 \text { PLHIV } \\
64 \% \text { females }\end{array}$ & $\begin{array}{l}\text { WHO ICF checklist, } \\
\text { dynamometry, } \\
\text { Oxford muscle } \\
\text { testing, goniometry }\end{array}$ & - All ICF domains \\
\hline $\begin{array}{l}\text { Van } \\
\text { Marle et } \\
\text { al. (2009) }\end{array}$ & $\begin{array}{l}\text { HIV-occlusive } \\
\text { vascular disease }\end{array}$ & $\begin{array}{l}\text { South } \\
\text { Africa: } \\
\text { urban }\end{array}$ & $\begin{array}{l}\text { Prospective } \\
\text { clinical survey }\end{array}$ & $\begin{array}{l}\mathrm{N}=154 \text { PLHIV } \\
\text { admitted to vascular } \\
\text { unit, } \mathrm{N}=20 \\
\text { females }\end{array}$ & $\begin{array}{l}\text { CD4 and CD8 T-cell } \\
\text { counts, viral load, } \\
\text { screening for other } \\
\text { sexually transmitted } \\
\text { infections; arterial } \\
\text { Duplex Doppler } \\
\text { scans, patient } \\
\text { questionnaire }\end{array}$ & - B430: lifting and caring objects \\
\hline $\begin{array}{l}\text { Wouters } \\
\text { et al. } \\
(2009)\end{array}$ & $\begin{array}{l}\text { Physical and } \\
\text { emotional health } \\
\text { outcomes after } 12 \\
\text { months of } \\
\text { public-sector } \\
\text { antiretroviral } \\
\text { treatment in the free } \\
\text { state province of } \\
\text { South Africa: a } \\
\text { longitudinal study } \\
\text { using structural } \\
\text { equation modelling }\end{array}$ & $\begin{array}{l}\text { South } \\
\text { Africa: } \\
\text { urban and } \\
\text { rural }\end{array}$ & $\begin{array}{l}\text { Longitudinal } \\
\text { cross-sectional } \\
\text { study }\end{array}$ & $\begin{array}{l}\mathrm{N}=268 \text { PLHIV } \\
\text { ready for } \mathrm{ART} \\
67 \% \text { females }\end{array}$ & $\begin{array}{l}\text { Euro QoL 5D, } \\
\text { subjective well-being } \\
\text { (i.e. self-report)- } \\
\text { assess five generic } \\
\text { aspects of current } \\
\text { health (mobility, } \\
\text { self-care, limitation } \\
\text { of activities, pain, } \\
\text { and mood) }\end{array}$ & - B280: pain \\
\hline $\begin{array}{l}\text { Wouters } \\
\text { et al. } \\
(2007)\end{array}$ & $\begin{array}{l}\text { Short-term physical } \\
\text { and emotional health } \\
\text { outcomes of public } \\
\text { sector ART in the } \\
\text { free state province of } \\
\text { South Africa }\end{array}$ & $\begin{array}{l}\text { South } \\
\text { Africa: } \\
\text { urban and } \\
\text { rural }\end{array}$ & $\begin{array}{l}\text { Cross sectional/ } \\
\text { prevalence } \\
\text { study }\end{array}$ & $\begin{array}{l}\mathrm{N}=371 \mathrm{PLHIV} \\
\text { ready for ART } \\
\text { Gender unspecified }\end{array}$ & EuroQoL 5D & $\begin{array}{l}\text { - B152: physical health } \\
\text { - D4: mobility }\end{array}$ \\
\hline $\begin{array}{l}\text { Yengopal } \\
\text { et al. } \\
(2008)\end{array}$ & $\begin{array}{l}\text { Do oral lesions } \\
\text { associated with HIV } \\
\text { affect quality of life? }\end{array}$ & $\begin{array}{l}\text { South } \\
\text { Africa: } \\
\text { urban }\end{array}$ & $\begin{array}{l}\text { Cross-sectional } \\
\text { analytic study }\end{array}$ & $\begin{array}{l}\mathrm{N}=150 \text { PLHIV with } \\
\text { and without oral } \\
\text { manifestations of } \\
\text { HIV, gender } \\
\text { unspecified }\end{array}$ & $\begin{array}{l}\text { HIV Adult Oral } \\
\text { Health Status Data } \\
\text { Capture Sheet, OHIP }\end{array}$ & $\begin{array}{l}\text { - } \text { B8: skin and others } \\
\text { - } \text { B280: pain } \\
\text { - } \text { B515: oral function problems } \\
\text { related to problems with digesting } \\
\text { food } \\
\text { - } \text { B3: speaking } \\
\text { - B2: looks, smell, taste } \\
\text { - } \text { B515: digestion }\end{array}$ \\
\hline $\begin{array}{l}\text { Zeegers et } \\
\text { al. (2010) }\end{array}$ & $\begin{array}{l}\text { Attention deficit } \\
\text { hyperactivity and } \\
\text { oppositional defiance } \\
\text { disorder in } \\
\text { HIV-infected South } \\
\text { African children }\end{array}$ & $\begin{array}{l}\text { South } \\
\text { Africa: } \\
\text { urban }\end{array}$ & $\begin{array}{l}\text { Retrospective } \\
\text { medical record } \\
\text { review }\end{array}$ & $\begin{array}{l}\mathrm{N}=100 \\
\text { HIV-infected } \\
\text { children ( } \geq 5 \text { years }) \\
49 \% \text { girls }\end{array}$ & $\begin{array}{l}\text { SNAP-IV, } \\
\text { Goodenough } \\
\text { draw-a-person (DAP) }\end{array}$ & - B140: concentration/attention \\
\hline
\end{tabular}

Myezwa et al. revealed impairments related to digestive, metabolic or endocrine systems in $83.9 \%$ of their sample. Similarly in the study by van As et al., $44 \%$ of the sample experienced digestive, metabolic or endocrine problems $[25,26]$. Julius et al. indicated a prevalence of diabetes of $20.4 \%$, with $16.8 \%$ obese and $28.6 \%$ overweight in the sample [43], although these data were not compared to HIV-negative controls.

Genitourinary and reproductive function (b6): Four studies reported data on functions of the genitourinary and reproductive systems. Van As et al. [26] showed that $31 \%$ of the sample experienced genitourinary or repro- ductive problems. Bhat et al. [38] reported problems with sexual functions in $8.9 \%$ of their sample of 168 participants. Renal function was explored in larger trials. Franey et al. reported renal problems in $1.3 \%$ of their sample of 2189 PLHIV who are on treatment. Both Franey et al. and Jao et al. [44,45] found increased renal impairment at ART onset with men more affected than women.

Muscle function and related tissue (b7): Nine articles (describing eight studies) provided data on the extent of impairments related to muscle tone, power and motor development as well as the functions of the skin and related structures. Myezwa et al. revealed neuromuscu- 


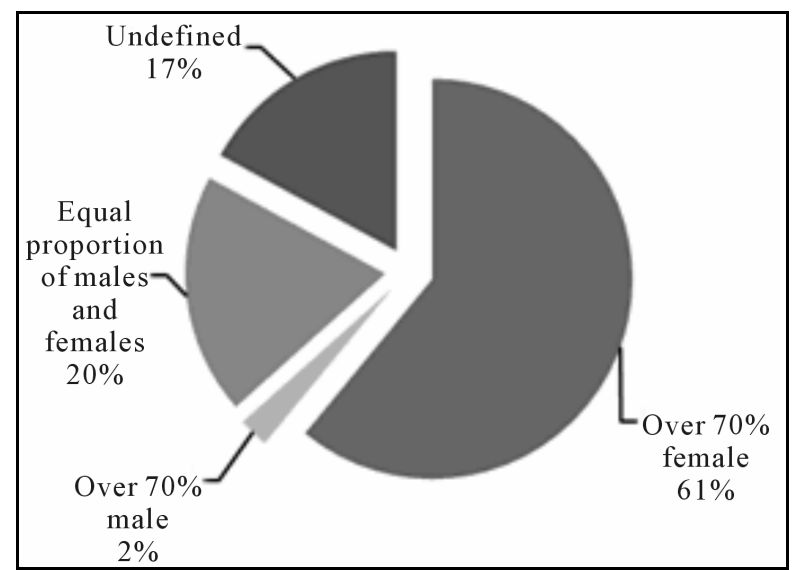

Figure 3. Proportion of women and men in included studies.

loskeletal movement impairment in $73.8 \%$ and muscle power loss in $75 \%$ of their sample [25]. Van As et al. reported that $31 \%$ of the sample experienced skin impairments and for $27 \%$ the most common neuromuscular problem was loss of muscle power. Focusing on fine and gross motor skills, Ferguson et al. $[46,47]$ reported motor delay in their study of 86 HIV-positive children with matched controls. Significant motor delay was $66.7 \%$ in the HIV-positive sample, which was significantly higher than the age-matched compared. Bhat et al. reported problems with skin rashes in $8.3 \%$ and with hair loss in $7.7 \%$ of the sample. Franey et al., Friend-du Preez et al. Oketcha et al. and Yengopal et al. also reported problems associated with the function of skin and related structures [40-42,44].

\subsection{Activity Limitations and Participation Restrictions}

In contrast to the level of impairment, far less data were reported on the ICF levels of activity or participation. Studies that did report on these concepts are described below according to the ICF domains of mobility, selfcare, and community, social and civic life. Several studies also reported elements of "learning and applying knowledge", which includes problem-solving, or "communication". There was little information related to contextual factors, such as access to services, technology, support and relationships and attitudes.

Mobility (d4): Eight studies reported problems with mobility, mainly for PLHIV on treatment. Myezwa et al. $[7,25]$ found mobility limitations in $56.4 \%$ of the sample, while van As et al. [26], using the same framework, found mobility limitations in $40 \%$ of the sample, especially lifting and carrying. These complaints were associated with mild difficulty undertaking multiple tasks without assistance. Similarly, Nair and Patel reported decreased physical functioning as measured by mobility. The studies by Wouthers et al., Booysen et al., Kakinami et al., and McInnerney et al. [32,33,48-50] reported improvement in mobility upon initiating ART, with participants followed for the first 12 or 18 months. The study by Karbore et al. [51] showed that among participants not receiving community services (i.e., food and homebased care), the mean physical functioning score increased by 1.6 points to 11.2 at 12 months but then decreased to 10.6 at 18 months, while the group which received community services improved continuously.

Self-care (d5): Three studies described data on selfcare. Oketch et al. [42] reported minor (80.6\%), moderate $(14 \%)$, or severe $(5.4 \%)$ problems with self-care. The studies by Booysen et al. [48], Jelsma et al. [15] and Kakinamis et al. [49] each showed improvements in the domain of self-care during the first year of ART. Data over a longer period were not available.

Community, social and civic life (d9): Two studies reported data in this domain. Myezwa et al. reported that activity limitations were present in major life areas (55.1\%), and community, social and civic life (50\%), and that many of those activity limitations were associated with impairments [25]. They also reported that activity limitations or participation restrictions, including difficulties with general tasks and demands, interpersonal relationships, domestic life, and community, social and civic life, were closely associated with barriers in obtaining products for personal use and in using technology. Van As et al. [26] showed that participants had challenges in major life areas $(58 \%)$, and that interpersonal interactions and relationships $(56 \%)$ were most common. Of these, challenges related to school, higher education and remunerative employment were specifically problematic.

\subsection{Linkages among Impairment, Activity and Participation Levels}

Few studies explored how the different domains might be associated with each other. Nair et al. [52] reported that Perceived Social Support was correlated with vitality $(\mathrm{r}=$ $0.28, \mathrm{p}<0.01)$ and mental health $(\mathrm{r}=0.26, \mathrm{p}<0.01)$, suggesting that high levels of social support from family and friends are related to good mental health in the participants. Gupta et al. [53] reported that depression was associated with stigma and relationship problems. Nair et al. also reported how a low score on the SF-36 Bodily Pain Scale was associated with compromised ability to work.

The four studies that addressed contextual factors reported that certain impairments or activity limitations were associated with domains such as access to products and technology $[25,31,54]$. Simbavi et al. demonstrated how challenges within the ICF domain of emotional functions were related to problems with support and relationships [55].

Finally, linkages between dimensions of disability and 
ART adherence received little attention in the available literature. Bhat et al. [38] reported that reasons given by participants for ART adherence problems included that they "simply forgot" $(41.3 \%)$ or were attributed to the "side effects" of ART (50.8\%). They also reported that HIV-related impairments or "side effects" were greatly increased in the portion of the sample that did not adhere to treatment, and that the reason for skipping the dose was often because of these side effects.

\section{Discussion}

This is the first analysis to systematically review the literature on HIV-related outcomes among people living with HIV in hyper-endemic countries within a disability framework. In the era of enhanced access to ART, many people will be living longer lives but with potential episodes of disability resulting from HIV, HIV-related conditions, and/or as side effects of ART. It is crucial to understand the extent of disability among people living with HIV in high-prevalence settings in order to inform choices regarding care, policy and research. These findings add to the growing body of literature that calls for attention to disability in high HIV-prevalence settings [4-7,16,56-59]. In particular, this scoping review demonstrates that much is already known about impairments, activity limitations and participation restrictions experienced by people living with HIV in hyper-endemic countries, but that key gaps in understanding remain.

\subsection{What Is Known and Unknown about HIV-Related Disability in Hyper-Endemic Countries?}

This review identified literature that reports data on all concepts within the ICF schematic of disability (see Figure 1), but in vastly unequal ways. By far, impairments in body structure and function comprise the majority of data available on disability experienced by people living with HIV in hyper-endemic countries. Most of the included studies report on some form of impairment, and all of the first level ICF impairment codes were addressed except for one ("b3 Voice"). Particularly striking is the extent of data reported on impairments related to mental functions, which is an area of disability that can be overshadowed by physical concerns. This mirrors the findings of the population-based disability prevalence study of people living with HIV in British Columbia, in which the prevalence of mental impairments was $78 \%$ [12].

Rusch et al. also reported a high prevalence of concurrent impairments, with a median of 7 impairments and approximately one-third of the sample experiencing more than ten impairments in the past month [12]. Similarly, our scoping study found multiple diverse impairments being reported. However, a striking finding is that none of the included articles reported data on the sensory functions of hearing and seeing, despite the fact that HIV and its opportunistic diseases can cause these impairments [60]. Furthermore, few studies addressed functions of the cardiovascular and respiratory systems, even though tuberculosis and lipodystrophy are well-described health conditions associated with HIV.

Whereas Rusch et al. also reported high rates of activity limitations (80\%) and participation restrictions (93), few studies included in this review addressed these levels of concern. Studies that did attend to these issues focused primarily on self-care, mobility and engagement in community. While some studies indicated improvement of these areas following onset of ART, [15,48-50] others reported that a large number of PLHIV continue to experience challenges related to these areas [61,62]. A longitudinal study using a comprehensive disability measure could enhance understanding of the shifting experience of activity limitations and participation restrictions over time. In addition to these areas, future research is needed to better understand domains not commonly included in outcome studies, such as communication, domestic life, and education.

The review also found very little data on contextual factors, which include availability of assistance devices, rehabilitation and social support in the context of HIV. The importance of these environmental factors can be crucial in mitigating activity limitations and participation restrictions. We note that data on contextual factors may more commonly be found in qualitative studies; however, the adage that "what gets counted counts" emphasizes the importance of quantifying outcomes across the holistic experience of disability in order to inform action.

A key direction for future research is investigation of linkages between HIV-related disability and ART adherence. The multi-faceted challenge could gain from better understanding how various dimensions of disability contribute to ART adherence or attrition. We also note the dearth of data related to disability among HIVpositive children and youth, indicating another priority for future research.

\subsection{Contributions of a Disability Framework to HIV Research}

An issue that arises from this review relates to the biomedical emphasis in HIV outcomes studies. The articles with the largest samples and thus the greatest opportunity to draw conclusions (at least within this research paradigm) typically focused on particular clinical concerns, without taking into account how these diagnoses might influence or be connected to other areas of health or life. It is therefore unsurprising that responses to HIV care are 
largely medicalized and often do not include or privilege rehabilitation [3] or other services that could significantly improve quality of life. This is not to diminish the importance of biomedical approaches, and medicines in particular, to the experience of living with HIV. However, we argue that the time has come to elevate the health and life-related consequences of living with HIV to the status given to surrogate markers of disease progression.

Lack of data can lead to lack of responses that could strengthen HIV care. An advantage of the ICF is the way that each concept in the schematic can influence and be influenced by the other concepts, as illustrated by the double-headed arrows (see Figure 1). This framing acknowledges the complexity of life and challenges researchers to consider not only the concepts but their interactions. Only a few studies explored interactions between concepts, yet these findings provide important insights not only on the experience of disability but also on opportunities for providing support. For example, Nair et al. reported on links between pain and ability to work, pointing to the potential that pain management might play in reducing attrition from work. A more comprehensive approach to HIV care that includes broader concerns with function and activity is needed to inform other responses, such as rehabilitation and community interventions that could complement ART. Using a disability lens in the context of HIV has the potential to connect the medical field to others that address opportunities to promote human activity and participation.

By far the most comprehensive approach to disability and HIV in this scoping review was undertaken in the studies by Myezwa et al. and van As et al. Both studies used the ICF checklist as a tool of investigation. As a result, these two articles provide data across impairment, activity limitations and participation restriction levels like no other study in this review. Myezwa et al. were able to demonstrate that difficulties with general tasks and demands, interpersonal relationships, domestic life and/or community, social and civic life are associated with barriers in obtaining products for personal use and using technology. This highlights the importance of assessing contextual factors as well. Studies that used the ICF provide a more holistic understanding of the experience of living with HIV, and a link between the diagnoses of health conditions on the one hand, and the identification of impairments, activity limitations and participation restrictions on the other.

\subsection{Limitations}

The extent to which our review's findings can be generalised to reflect HIV-related disability in hyper-endemic countries is limited in three important ways: geographic and location issues, constraints of sampling approaches, and concerns with sample sizes.

First, $78 \%$ of the studies were conducted in South Africa in contrast to just one study in Zimbabwe and none in Lesotho or Swaziland. Furthermore, all studies were conducted in public health care settings, which are more likely to include participants with lower socioeconomic status and less access to education and resources. As such, study results related to experiences of disability could be influenced by factors other than HIV. Future research needs to include matched control groups to clarify the degree to which disability is HIV-related.

Secondly, most studies in this sample used convenience sampling; only three studies (7\%) used random sampling. As such, findings are likely to reflect the kinds of individuals who more frequently attend the recruitment settings. Most of the studies in this review included more women than men. HIV prevalence in Southern Africa is higher in women, and women may be more likely than men to seek health services. As such, results may erroneously give the impression of certain experiences being more common among women than men. Conversely, the study by van Marle et al. included more males than females [63]. However, the study focused on HIV-occlusive vascular disease, which may be more prevalent in men in the general population. Therefore, it would be inappropriate to make claims about gendered differences in the extent of disability related to this condition.

Thirdly, the studies in this review with the largest sample sizes $(n>1000)$ focused on particular health conditions, such as renal failure or neurological disorders. Studies that took a broad view of disability had relatively small samples $(\mathrm{n}<100)$. As such, we may draw only limited conclusions about the extent of disability in PLHIV. A population-based prevalence study of disability (understood comprehensively, as in the ICF) would mitigate each of these methodological concerns.

\section{Conclusion}

This scoping review described the literature on disability experienced by people living with HIV in hyper-epidemic countries since expanded access to ART in the mid-2000s. A key innovation in this study is the way that we have conceptualized HIV-related disability in Southern Africa using the World Health Organization's ICF. We hope that this review will prompt consideration of disability issues and inclusion of people with disabilities in our collective thinking about HIV in the region.

\section{Acknowledgements and Funding}

We thank Peggy-Rae Carswell for her support as a research assistant. Stephanie Nixon is supported by the Canadian Institutes for Health Research. Ilaria Regondi's 
time at HEARD was made possible by the UK's Overseas Development Institute.

\section{REFERENCES}

[1] UNAIDS, "Global Report: UNAIDS Report on the Global AIDS Epidemic 2010," UNAIDS, Geneva, 2010. http://www.unaids.org/documents/20101123_GlobalRepo rt_Foreword_em.pdf

[2] UNAIDS, "UNIADS World AIDS Day Report 2011. How to Get to Zero: Faster. Smarter. Better," UNAIDS, Geneva, 2011.

[3] G. Meintjes, G. Maartens, A. Boulle, F. Conradie, E. Goemaere, E. Hefer, D. Johnson, M. Mathe, Y. Moosa, R. Osih, T. Rossouw, G. van Cutsem, E. Variava, F. Venter and D. Spencer, "Guidelines for Antiretroviral Therapy in Adults," Southern African Journal of HIV Medicine, Vol. 13, No. 3, 2012, pp. 114-130.

[4] S. Nixon, J. Hanass-Hancock, A. Whiteside and T. Barnett, "The Increasing Chronicity of HIV in Sub-Saharan Africa: Re-Thinking 'HIV as a Long-Wave Event' in the Era of Widespread Access to ART," Globalisation and Health, Vol. 7, No. 41, 2011, pp. 1-5. http://www.globalizationandhealth.com/content/7/1/41

[5] K. O'Brien, A. M. Bayoumi, C. Strike, N. Young and A. M. Davis, "Exploring Disability from the Perspective of Adults Living with HIV/AIDS: Development of a Conceptual Framework," Health and Quality of Life Outcomes, Vol. 6, 2008, p. 76.

[6] K. O'Brien, A. Wilkins, E. Zack and P. Solomon, "Scoping the Field: Identifying Key Research Priorities in HIV and Rehabilitation," AIDS and Behavior, Vol. 14, No. 2, 2010, pp. 448-458.

[7] H. Myezwa, C. M. Buchalla, J. Jelsma and A. Stewart, "HIV/AIDS: Use of the ICF in Brazil and South Africa -Comparative Data from Four Cross-Sectional Studies," Physiotherapy, Vol. 97, No. 1, 2011, pp. 17-25.

[8] S. Nixon and C. Cott, "Shifting Perspectives: Reconceptualizing HIV Disease in a Rehabilitation Framework," Physiotherapy Canada, Vol. 52, 2000, pp. 189-197.

[9] J. Hanass-Hancock and S. Nixon, "The Fields of HIV and Disability: Past, Present and Future," Journal of the International AIDS Society, Vol. 12, No. 28, 2009, pp. 1-8. http://www.jiasociety.org/series/hiv_aids_and_disability

[10] WHO, "ICF, Towards a Common Language for Functioning, Disability and Health," 2002.

[11] K. O'Brien, A. M. Davis, C. Strike, N. L. Young and A. M. Bayoumi, "Putting Episodic Disability into Context: A Qualitative Study Exploring Factors that Influence Disability Experienced by Adults Living with HIV/AIDS," Journal of the International AIDS Society, Vol. 12, No. 30, 2009, pp. 1-7. www.jiasociety.org/content/12/1/30

[12] M. Rusch, S. Nixon, A. Schilder, P. Braitstein, K. Chan, and R. Hogg, "Impairments, Activity Limitations and Participation Restrictions: Prevalence and Associations among Persons Living with HIV/AIDS in British Columbia," Health and Quality of Life Outcomes, Vol. 2, No. 1, 2004, p. 46. doi:10.1186/1477-7525-2-46
[13] M. Rusch, S. Nixon, A. Schilder, P. Braitstein, K. Chan, and R. Hogg, "Prevalence of Activity Limitation among Persons Living with HIV/AIDS in British Columbia," Canadian Journal of Public Health, Vol. 95, No. 6, 2004, pp. 437-440.

[14] Canadian Working Group on HIV and Rehabilitation, "HIV, Disability and Rehabilitation: Promoting Quality of Life through Research, Education and Cross-Sector partnership. Strategic Plan: 2010-2013,” 2010. http://www.hivandrehab.ca/EN/about_us/documents/CW GHRStrategicPlanFinal.pdf

[15] J. Jelsma, E. Maclean, J. Hughes, X. Tinise and M. Darder, "An Investigation into the Health-Related Quality of Life of Individuals Living with HIV Who Are Receiving HAART," AIDS Care, Vol. 17, No. 5, 2005, pp. 579588. doi:10.1080/09540120412331319714

[16] J. Jelsma, N. Rbrauer, A. Snoek and I. Sykes, "A Pilot Study to Investigate the Use of the ICF in Documenting Levels of Function and Disability in People Living with HIV," South African Journal of Physiotherapy, Vol. 62, No. 7, 2006, pp. 7-13.

[17] J. Hanass-Hancock, S. Nixon, H. Myeswa, L. Van Eggerat and A. Gibbs, "Nathi Singabantu' an Exploratory Study of HIV-related Disability in KwaZulu-Natal," HEARD, Durban, 2012.

[18] T. B. Üstün, S. Chatterji, J. E. Bickenbach, T. T. I. Robert, R. Room, J. Rehm and S. Shekhar, "Disability and Culture: Universalism and Diversity," Hogrefe \& Huber, Seattle, 2001.

[19] WHO, "ICF Checklist. Version 2 1a, Clinician Form," WHO, Geneva, 2003.

[20] M. Nyirenda, S. Chatterji, J. Falkingham, P. Mutevedz, V. Hosegood, M. Evandrou, P. Kowal and M.-L. Newell, "An Investigation of Factors Associated with the Health and Well-Being of HIV-Infected or HIV-Affected Older People in Rural South Africa," BMC Public Health, Vol. 12, No. 259, 2012, pp. 1471-2458.

[21] H. Arksey and L. O’Malley, "Scoping Studies: Towards a Methodological Framework," International Journal of Social Research Methodology, Vol. 8, No. 1, 2005, pp. 19-32. doi:10.1080/1364557032000119616

[22] D. Levac, H. Colquhoun and K. O'Brien, "Scoping Studies: Advancing the Methodology," Implementation Science, Vol. 1, 2010, p. 69.

[23] D. Denyer and D. Tranfield, "Using Qualitative Research Synthesis to Build an Actionable Knowledge Base," Management Decision, Vol. 44, No. 2, 2006, pp. 214227. doi:10.1108/00251740610650201

[24] D. Tranfield, D. Denyer and P. Smart, "Towards a Methodology for Developing Evidence-Informed Management Knowledge by Means of Systematic Review," British Journal of Management, Vol. 14, No. 3, 2003, pp. $207-$ 222.

[25] H. Myezwa, A. Stewart, E. Musenge and P. Nesara, "Assessment of HIV-Positive In-Patients Using the International Classification of Functioning, Disability and Health (ICF), at Chris Hani Baragwanath Hospital, Johannesburg," African Journal of AIDS Research, Vol. 8, No. 1, 2009, pp. 93-106. 
[26] M. Van As, H. Myezwa, A. Stewart, D. Maleka, and E. Musenge, "The International Classification of Functioning Disability and Health (ICF) in Adults Visiting the HIV Outpatient Clinic at a Regional Hospital in Johannesburg, South Africa," AIDS Care, Vol. 21, No. 1, 2009, pp. 50-58. doi:10.1080/09540120802068829

[27] M. Freeman, N. Nkomo, Z. Kafaar and K. Kelly, "Factors Associated with Prevalence of Mental Disorder in People Living with HIV/AIDS in South Africa," AIDS Care, Vol. 19, No. 10, 2007, pp. 1201-1209. doi:10.1080/09540120701426482

[28] A. Kagee and L. Martin, "Symptoms of Depression and Anxiety among a Sample of South African Patients Living with HIV," AIDS Care, Vol. 22, No. 2, 2010, pp. 159165. doi:10.1080/09540120903111445

[29] M. Moosa, F. Jeenah and M. Vorster, "HIV in South Africa-Depression and CD4 Count," South African Journal of Psychiatry, Vol. 11, No. 1, 2005, pp. 12-15.

[30] L. Myer, J. Smit, L. Le Roux, S. Parker, D. J. Stein and S. Seedat, "Common Mental Disorders among HIV-Infected Individuals in South Africa: Prevalence, Predictors, and Validation of Brief Psychiatric Rating Scales," AIDS Patient Care and STDs, Vol. 22, No. 2, 2008, pp. 147-158.

[31] T. J. Rochat, L. M. Richter, H. A. Doll, N. P. Buthelezi, A. Tomkins and A. Stein, "Depression among Pregnant Rural South African Women Undergoing HIV Testing," Journal of the American Medical Association, Vol. 295, No. 12, 2006, pp. 1376-1378. doi:10.1001/jama.295.12.1376

[32] E. Wouters, C. Heunis, D. van Rensburg and H. Meulemans, "Physical and Emotional Health Outcomes after 12 Months of Public-Sector Antiretroviral Treatment in the Free State Province of South Africa: A Longitudinal Study Using Structural Equation Modelling," BMC Public Health, Vol. 9, No. 103, 2009, pp. 1-8.

[33] E. Wouters, H. Meulemans, H. C. Van Rensburg, J. C. Heunis and D. Mortelmans, "Short-Term Physical and Emotional Health Outcomes of Public Sector ART in the Free State province of South Africa," Quality of Life Research, Vol. 16, No. 9, 2007, pp. 1461-1471. doi:10.1007/s11136-007-9260-y

[34] R. Patel, S. Kassaye, C. Gore-Felton, G. Wyshak, G. Kadzirange, G. Woelk and D. Katzenstein, "Quality of Life, Psychosocial Health, and Antiretroviral Therapy among HIV-Positive Women in Zimbabwe," AIDS Care, Vol. 21, No. 12, 2009, pp. 1517-1527. doi:10.1080/09540120902923055

[35] K. Lawler, M. Mosepele, S. Ratcliffe, E. Seloilwe, K. Steele, R. Nthobatsang and A. Steenhoff, "Neurocognitive Impairment among HIV-Positive Individuals in Botswana: A Pilot Study," Journal of the International AIDS Society, Vol. 13, 2010, p. 15.

[36] J. A. Joska, D. S. Fincham, D. J. Stein, R. H. Paul and S. Seedat, "Clinical Correlates of HIV-Associated Neurocognitive Disorders in South Africa," AIDS and Behavior, Vol. 14, No. 2, 2010, pp. 371-378. doi:10.1007/s10461-009-9538-x

[37] K. Lawler, K. Jeremiah, M. Mosepele, S. J. Ratcliffe, C. Cherry, E. Seloilwe and A. P. Steenhoff, "Neurobeha- vioral Effects in HIV-Positive Individuals Receiving Highly Active Antiretroviral Therapy (HAART) in Gaborone, Botswana," PLoS One, Vol. 6, No. 2, 2011, Article ID: e17233. doi:10.1371/journal.pone.0017233

[38] V. G. Bhat, M. Ramburuth, M. Singh, O. Titi, A. P. Antony, L. Chiya, E. M. Irusen, P. P. Mtyapi, M. E. Mofoka, A. Zibeke, L. A. Chere-Sao, N. Gwadiso, N. C. Sethathi, S. R. Mbondwana and M. Msengana, "Factors Associated with Poor Adherence to Anti-Retroviral Therapy in Patients Attending a Rural Health Centre in South Africa," European Journal of Clinical Microbiology \& Infectious Diseases, Vol. 29, No. 8, 2010, pp. 947-953. doi:10.1007/s10096-010-0949-4

[39] J. Maritz, M. Benatar, J. A. Dave, T. B. Harrison, M. Badri, N. S. Levitt and J. M. Heckmann, "HIV Neuropathy in South Africans: Frequency, Characteristics, and Risk Factors," Muscle Nerve, Vol. 41, No. 5, 2010, pp. 599-606.

[40] V. Yengopal and S. Naidoo, "Do Oral Lesions Associated with HIV Affect Quality of Life?" Oral Surgery, Oral Medicine, Oral Pathology, Oral Radiology and Endodontology, Vol. 106, No. 1, 2008, pp. 66-73. doi:10.1016/j.tripleo.2007.12.024

[41] N. Friend-du Preez and K. Peltzer, "HIV Symptoms and Health-Related Quality of Life Prior to Initiation of HAART in a Sample of HIV-Positive South Africans," AIDS and Behavior, Vol. 14, No. 6, 2010, pp. 1437-1447. doi:10.1007/s10461-009-9566-6

[42] J. A. Oketch, M. Paterson, E. W. Maunder and N. C. Rollins, "Too Little, Too Late: Comparison of Nutritional Status and Quality of Life of Nutrition Care and Support Recipient and Non-Recipients among HIV-Positive Adults in KwaZulu-Natal, South Africa," Health Policy, Vol. 99, No. 3, 2011, pp. 267-276. doi:10.1016/j.healthpol.2010.08.018

[43] A. Kagee, "Psychological Distress among Persons Living with HIV, Hypertension, and Diabetes," AIDS Care, Vol. 22, No. 12, 2010, pp. 1517-1521. doi:10.1080/09540121.2010.484458

[44] C. Franey, D. Knott, T. Barnighausen, M. Dedicoat, A. Adam, R. J. Lessells, M. L. Newell and G. S. Cooke, "Renal Impairment in a Rural African Antiretroviral Programme," BMC Infectious Disease, Vol. 9, No. 143, 2009, pp. 1-8.

[45] J. Jao, W. Lo, P. L. Toro, C. Wyatt, D. Palmer, E. J. Abrams, R. J. Carter and M. T.-P. Initiative, "Factors Associated With Decreased Kidney Function in HIV-Infected Adults Enrolled in the MTCT-Plus Initiative in Sub-Saharan Africa," Journal of Acquired Immune Deficiency Syndromes, Vol. 57, No. 1, 2011, pp. 40-45. doi:10.1097/QAI.0b013e31821008eb

[46] G. Ferguson and J. Jelsma, "The Prevalence of Motor Delay among HIV Infected Children Living in Cape Town, South Africa," International Journal of Rehabilitation Research, Vol. 32, No. 2, 2009, pp. 108-114. doi:10.1097/MRR.0b013e3283013b34

[47] J. Jelsma and G. Ferguson, "Motor Development in Children Living within Resource Poor Areas of Western Cape," Physiotherapy, Vol. 63, No. 2, 2007, pp. 35-40. 
[48] F. Booysen, H. Van Rensburg, M. Bachmann, G. Louwagie and L. Fairall, "The Heart in HAART: Quality of Life of Patients Enrolled in the Public-Sector Antiretroviral Treatment Programme in the Free State Province of South Africa," Social Indicators Research, Vol. 81, 2007, pp. 283-329.

[49] L. Kakinami, G. de Bruyn, P. Pronyk, L. Mohapi, N. Tshabangu, M. Moshabela, J. McIntyre and N. A. Martinson, "The Impact of Highly Active Antiretroviral Therapy on Activities of Daily Living in HIV-Infected Adults in South Africa," AIDS and Behavior, Vol. 15, No. 4, 2011, pp. 823-831. doi:10.1007/s10461-010-9776-y

[50] P. A. McInerney, B. P. Ncama, D. Wantland, B. R. Bhengu, C. McGibbon, S. M. Davis, I. B. Corless and P. K. Nicholas, "Quality of Life and Physical Functioning in HIV-Infected Individuals Receiving Antiretroviral Therapy in KwaZulu-Natal, South Africa," Nursing \& Health Sciences, Vol. 10, No. 4, 2008, pp. 266-272. doi:10.1111/j.1442-2018.2008.00410.x

[51] I. Kabore, J. Bloem, G. Etheredge, W. Obiero, S. Wanless, P. Doykos, P. Ntsekhe, N. Mtshali, E. Afrikaner, R. Sayed, J. Bostwelelo, A. Hani, T. Moshabesha, A. Kalaka, J. Mameja, N. Zwane, N. Shongwe, P. Mtshali, B. Mohr, A. Smuts and A. Tiam, "The Effect of Community-Based Support Services on Clinical Efficacy and Health-Related Quality of Life in HIV/AIDS Patients in Resource-Limited Settings in Sub-Saharan Africa," AIDS Patient Care and STDs, Vol. 24, No. 9, 2010, pp. 581-594. doi:10.1089/apc.2009.0307

[52] K. M. Nair and N. Muthukrishna, "Psychological WellBeing and Health Related Quality of Life among a Group of Low-Income Women Living with HIV/AIDS in South Africa," Journal of Psychology in Africa, Vol. 19, No. 4, 2009, pp. 517-529.

[53] R. Gupta, M. Dandu, L. Packel, G. Rutherford, K. Leiter, N. Phaladze, F. P. Korte, V. Iacopino and S. D. Weiser, "Depression and HIV in Botswana: A Population-Based Study on Gender-Specific Socioeconomic and Behavioral Correlates," PLoS One, Vol. 5, No. 12, 2010, Article ID: e14252. doi:10.1371/journal.pone.0014252

[54] K. Peltzer and N. Phaswana-Mafuya, "Health-Related Quality of Life in a Sample of HIV-Infected South Africans," African Journal of AIDS Research, Vol. 7, No. 2,
2008, pp. 209-218.

[55] L. C. Simbayi, S. Kalichman, A. Strebel, A. Cloete, N. Henda and A. Mqeketo, "Internalized Stigma, Discrimination, and Depression among Men and Women Living with HIV/AIDS in Cape Town, South Africa," Social Science \& Medicine, Vol. 64, No. 9, 2007, pp. 1823-1831. doi:10.1016/j.socscimed.2007.01.006

[56] S. Nixon, L. Forman, J. Hanass-Hancock, M. Mac-Seing, N. Munyanukato, H. Myezwa and C. Retis, "Rehabilitation: A Crucial Component in the Future of HIV Care and Support," South African Journal of HIV Medicine, Vol. 12, No. 2, 2011, pp. 12-16.

[57] J. Jelsma, N. Davids and G. Ferguson, "The Motor Development of Orphaned Children with and without HIV: Pilot Exploration of Foster Care and Residential Placement," BMC Pediatrics, Vol. 11, 2011, p. 11.

[58] Canadian Working Group on HIV and Rehabilitation, "E-Module for Evidence-Informed HIV Rehabilitation," 2011.

[59] R. Brandt, "The Mental Health of People Living with HIV/AIDS in Africa: A Systematic Review," African Journal of AIDS Research, Vol. 8, No. 2, 2009, pp. 123133.

[60] HIV Insight, "Ophthalmic Manifestations of HIV," 2013. http://www.delta-search.com/?affID=110825\&tt=230113 srchd_0413_1\&babsrc $=$ HP_ss\&mntrId $=\mathrm{d} 2$ ba5ac600000 $0000000 \mathrm{ec} 55 \mathrm{f} 976 \mathrm{db} 6 \mathrm{~b}$

[61] H. Myezwa, C. M. Buchalla, J. Jelsma and A. Stewart, "HIV/AIDS: Use of the ICF in Brazil and South Africa-Comparative Data from Four Cross-Sectional Studies," Physiotherapy, Vol. 97, No. 1, 2011, pp. 17-25. doi:10.1016/j.physio.2010.08.015

[62] M. Van As, H. Myezwa, A. Stewart, D. Maleka and E. Musenge, "The International Classification of Function Disability and Health (ICF) in Adults Visiting the HIV Outpatient Clinic at a Regional Hospital in Johannesburg, South Africa," AIDS Care, Vol. 21, No. 1, 2009, pp. 5058.

[63] J. van Marle, P. P. Mistry and K. Botes, "HIV-Occlusive Vascular Disease," South African Journal of Surgery, Vol. 47, No. 2, 2009, pp. 36-42. 


\section{List of Abbreviations}

ARV: Antiretroviral

ART: Antiretroviral therapy

HAART: Highly active antiretroviral therapy

HAND: HIV-associated neurocognitive disorders

ICF: International Classification of Functioning, Disability and Health

IHDS: International HIV dementia scale

PLHIV: People living with HIV

PTSD: Post traumatic stress disorder

SF-36: Short Form 36

STD: Sexual Transmitted Disease

SRQ-20: Self Reported Questionaire 20

QAL: Quality of Life 